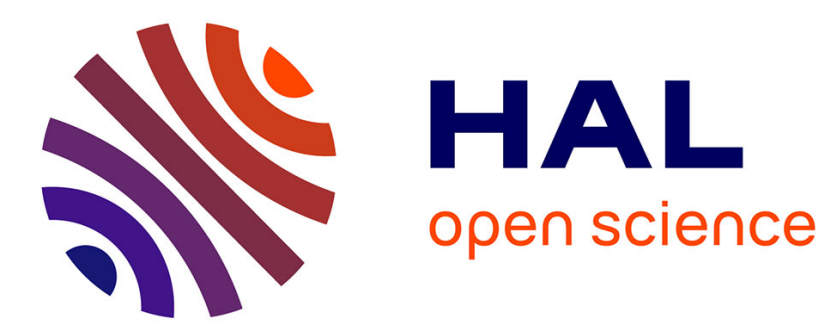

\title{
Increase in late Neogene denudation of the European Alps confirmed by analysis of a fission-track thermochronology database
}

\author{
Antoine Vernon, Pieter van Der Beek, Hugh Sinclair, Meinert Rahn
}

\section{To cite this version:}

Antoine Vernon, Pieter van Der Beek, Hugh Sinclair, Meinert Rahn. Increase in late Neogene denudation of the European Alps confirmed by analysis of a fission-track thermochronology database. Earth and Planetary Science Letters, 2008, 270 (3-4), pp.316-329. 10.1016/j.epsl.2008.03.053 . hal00286544

\section{HAL Id: hal-00286544 \\ https://hal.science/hal-00286544}

Submitted on 9 Jun 2008

HAL is a multi-disciplinary open access archive for the deposit and dissemination of scientific research documents, whether they are published or not. The documents may come from teaching and research institutions in France or abroad, or from public or private research centers.
L'archive ouverte pluridisciplinaire HAL, est destinée au dépôt et à la diffusion de documents scientifiques de niveau recherche, publiés ou non, émanant des établissements d'enseignement et de recherche français ou étrangers, des laboratoires publics ou privés. 


\section{Increase in late Neogene denudation of the European Alps}

\section{2 confirmed by isoage analysis of a fission-track database}

3 A.J. Vernon ${ }^{(1,2), *}$, P.A. van der Beek ${ }^{(2)}$, H.D. Sinclair ${ }^{(1)}$, M.K. Rahn ${ }^{(3)}$

4 (1) School of Geosciences, Grant Institute, University of Edinburgh, Edinburgh EH9-3JW, United-Kingdom

5 (2) Laboratoire de Géodynamique des Chaînes Alpines, Université Joseph Fourier, 38400 Grenoble, France

6 (3) Swiss Federal Nuclear Safety Inspectorate, 5232 Villigen-HSK, Switzerland

$7 \quad *$ Corresponding author: antoine.vernon@ed.ac.uk

\section{Abstract}

10 A sharp increase in deposited sediment volume since Pliocene times has been observed

11 worldwide and in particular around the European Alps. This phenomenon has been linked to a

12 rise in denudation rates controlled by an increase of either climatic or tectonic forcing.

13 Observation of in situ cooling histories for orogens is critical to assess the reality of the

14 inferred increase in denudation rates, and to determine whether this phenomenon is

15 widespread or localized at active tectonic structures. We exploit the unique density of fission

16 track ages in the Western European Alps to reconstruct cooling isoage surfaces and to

17 estimate exhumation rates on the orogen scale between 13.5 and 2.5 Ma. Our novel technique

18 is based on the association of isoage contours with age-elevation relationships. It uses map-

19 view interpolation, enabling a spatio-temporal analysis of exhumation rates over the entire

20 Western Alps. The resulting exhumation histories reconstructed for eight areas of the Western

21 Alps display strong similarities in timing and rates with orogen-wide average denudation rates

22 inferred from sediment volumes. This consistency validates the use of both techniques for the

23 study of an orogen characterized by strong relief and high recent exhumation rates. We

24 conclude that exhumation rates in the Western Alps have increased more than twofold since 
late Miocene times. This increase may have been locally modulated by the distinct response of different tectonic units.

Keywords: Cenozoic exhumation, Fission track, Isoage surfaces, Western Alps

\section{Introduction}

Widespread indications for an increase of global sedimentation rates in the early Pliocene have been reported from localities around the world (e.g., Molnar, 2004; Zhang et al., 2001). However, the cause of this event, its exact timing and synchronicity remain controversial. Possible causes that have been proposed include global cooling and incipient glaciations (Ehlers et al., 2006; Hinderer, 2001), an increase in the magnitude and frequency of climate oscillations (Molnar, 2004; Zhang et al., 2001), and a recent increase in the uplift rates of major orogens (Raymo and Ruddiman, 1992).

The quantification of sediment volumes in the basins surrounding the European Alps by Kuhlemann et al. (2002) shows a more than twofold increase in erosion rates in both the

Western and Eastern Alps around $5 \mathrm{Ma}$ (Figure 1). An independent study of the exhumation of the Molasse bassin (Figure 2), based on borehole apatite fission-track data, demonstrated approximately $1400 \mathrm{~m}$ of basin exhumation since $5 \mathrm{Ma}$, interpreted as a record of isostatic rebound of the basin driven by accelerated erosional unloading of the Alps (Cederbom et al., 2004).

7 The estimation of source-area denudation rates from the sediment record suffers, however, from poorly quantified uncertainties in both the volumetric calculations and the dating accuracy (Kuhlemann et al., 2002). Moreover, the impossibility of quantifying the roles of 
chemical erosion and sediment recycling may lead to an underestimation or overestimation, respectively, of source-area denudation rates.

An increase in exhumation at ca. $5 \mathrm{Ma}$, if real, should be recorded more directly by lowtemperature thermochronometers in the bedrock of the mountain belt. Classically, the derivation of exhumation rates from thermochronometry is based on temperature-time paths reconstructed from multiple thermochronometer analysis, age-elevation profiles from altitudinal transects or boreholes, or kinetic modeling of apatite fission-track annealing using track-length distributions (e.g., Gallagher et al., 1998; Hurford, 1991). In different regions of the Western Alps, Neogene-age exhumation rates quantified using these approaches range between 0.1 and $1.5 \mathrm{~mm} / \mathrm{yr}$ (e.g., Leloup et al., 2005; Malusa et al., 2005; Michalski and Soom, 1990; Tricart et al., 2007). However, most of these studies are local or at best regional in scope and a consistent denudation history at the orogen scale has yet to emerge. Apatite fission-track (AFT) thermochronology appears the most suitable technique to study MioPliocene exhumation rates over a large area such as the Western Alps because of the abundance of ages ready for database compilation, and because the AFT age range (Figure 3a) comprises the target period of the late Neogene.

The spatial integration of discrete thermochronological data covering large study areas is most easily achieved by interpolating between ages in map view (e.g., Hunziker et al., 1992;

Figures 3-a and 3-b). However, this simple technique only presents the integrated result of a possibly complex denudation history and does not allow variations in denudation rate through time to be inferred. Published methods aimed at describing the history of exhumation rates in map view have used either analysis of multiple thermochronometers, or kinetic modeling of fission-track length distributions (e.g., Bistacchi and Massironi, 2000; Gallagher and Brown, 
1999; Morris et al., 1998; Schlunegger and Willet, 1999; Stephenson et al., 2006). Despite many years of intensive thermochronological studies in the Alps, samples permitting such analyses are still relatively rare, disallowing such a study at the orogen scale. Techniques based on modeling of fission-track length distributions offer the greatest wealth of interpretation in settings characterized by slow long-term denudation, such as rifted continental margins (e.g. Gallagher and Brown, 1999). In rapidly exhuming orogens, in contrast, track-length distributions are not easily measured (because of generally young AFT ages) and are much less discriminative.

\section{(1)}

(1)

We propose a new method in which we exploit the extensive AFT dataset available for the Western Alps (Figures 2 and 3) together with the significant relief of the mountain belt to reconstruct three-dimensional surfaces of equal AFT age (referred to here as isoage surfaces).

We subsequently use the difference in elevation between these surfaces to estimate the spatial pattern in rates of exhumation back to middle Miocene times (13.5 Ma), as recorded in the spatial relationship between AFT ages at outcrop today. The aims of this study are to test for the presence of changing exhumation rates during late Neogene times across the Western Alps, and if present, to describe the temporal and spatial variability of this signal. In addition, we present updated maps of interpolated apatite fission-track ages and mean track lengths, as well as zircon fission-track ages. We complete this study by the assessment of evolving trends of exhumation rates using samples with paired zircon and apatite fission-track ages. In the following, we first briefly outline the geological setting and evolution of the Alps and present the thermochronological database we constructed. We then explain the different methods we used to analyze the database. Finally, we present our main results and their implications for the late Neogene denudation history of the Alps as well as its possible tectonic or climatic controls. 


\section{Geological setting of the Alps}

102 The European Alps (Figure 2) are located at the boundary between the European and Apulian 103 plates. They are the product of the early Cretaceous closure of the Piemont-Ligurian ocean, 104 followed by continental subduction resulting in nappe stacking (cf. reviews in Rosenbaum 105 and Lister, 2005; Schmid et al., 2004).

The main tectonic units in the Alps and their structural relationships have been described extensively within the last century (e.g., Debelmas and Lemoine, 1970; Schmid et al., 2004; Trümpy, 1960). They originate from the European continental margin basement (External Crystalline Massifs) and overlying deposits (Helvetic sediments), the Briançonnais micro-

111 continent and its two bordering oceanic units (Piemont-Ligure and Valais oceanic crust and flysh), and finally basement and sedimentary units of the Apulian margin, grouped as the Austroalpine and the South Alpine units (Figure 2). The North (Molasse) and South (Po) Alpine foreland basins formed by flexure of the lithosphere in response to the weight of the orogenic prism on the European and Apulian plates and are filled with Eocene to Recent flysch, molasse and glacial deposits (e.g., Homewood et al., 1986; Scardia et al., 2006).

One of the most important arc-parallel tectonic boundaries, the Penninic thrust, may have been extensionally reactivated (Seward and Mancktelow, 1994) as part of a series of Neogene extensional features observed throughout the axial region of the Western Alps (e.g., Sue et al., 121 2007; Tricart et al., 2007 and references therein). Most of these extensional features may be caused by a Neogene dextral transtensive event (Sue et al., 2007) triggered by the anticlockwise rotation of the Apulian plate. Such rotation can also explain the current strain 124 pattern in the Western Alps (Calais et al., 2002). At present, geodetic and GPS data show 
125 limited ( $\leq 2 \mathrm{~mm} / \mathrm{yr}$ ) east-west extension in the Western Alps (Calais et al, 2002; Sue et al., 126 2007). The lack of present-day convergence in the Western Alps, together with the 127 observation of sediment-sealed thrusts in the western part of the Po basin (Pieri and Groppi, 128 1981), and the cessation of thin-skinned deformation in the Jura at ca. $4 \mathrm{Ma}$ (Becker, 2000) all 129 suggest very limited current orogenic activity within the chain.

131 We limit our study area to the Western half of the Alps, as far east as the Silvretta nappe /

132 Engadine window, or approximately the Swiss-Austrian border, which marks the western 133 limit of widespread outcrop of Austroalpine units. The reason for this eastern limit to the 134 study area is that few AFT studies have been published for the Austroalpine units because of 135 the low abundance of apatite in their constitutive lithologies.

\subsection{Apatite and zircon fission-track databases}

139 During the last thirty-five years, the Western Alps have been extensively sampled for

140 thermochronological analyses, in particular using the apatite and zircon fission-track

141 thermochronometers, characterized by closure temperatures of ca. 120 and $240{ }^{\circ} \mathrm{C}$ respectively (e.g., Brandon et al., 1998; Gallagher et al., 1998). We have compiled 740 AFT ages, from data in 37 publications completed by 160 unpublished ages (references are given in the caption of Figure 3-a) from samples located in the European Alps west of $10^{\circ} 20^{\prime}$ east (an area of ca. $48000 \mathrm{~km}^{2}$ ). We similarly compiled 380 zircon fission-track (ZFT) ages from 24 publications completed by 22 unpublished ages (see Figure 3-b for references). 


\subsection{Quality and homogeneity of the data}

149 Early studies (in the 1970's and early 1980's, see for instance Wagner and Reimer, 1972)

150 used the population method for AFT dating, whereas the more reliable external detector

151 method (Hurford and Green, 1982) has become the norm since the mid 1980's. The database

152 contains ages obtained both with the population and the external-detector dating techniques

153 because we feel that, at the regional scale of the study, the benefits of increasing data density

154 outweigh the drawbacks of the error introduced by less reliable data points. We rejected three

155 samples with an obvious mistake in dating, in cases where a ZFT age was younger than or

156 equal to (within error) the AFT age of the same sample.

Additional information collected for each sample included (where reported): (1) geographic coordinates, (2) elevation, (3) mean track length for AFT samples, (4) whether the sample is from a tunnel / borehole or the surface, and (5) whether fission-track ages of samples from

161 Mesozoic and Cenozoic sediments are younger than their stratigraphic age (that is, whether they have been reset during Alpine orogeny). To apply the latter criterion, we assumed that ages from sedimentary samples were non-reset unless we could estimate the depositional age and verify that it was older than the fission-track age. A few publications contained more than one age at a given geographic location (referred to later as points with non-unique ages). We discarded such points from part of the study, in order to prevent problems with map interpolation. Many of the original publications did not report sample elevations and / or coordinates. We obtained this missing information by interviewing the authors whenever possible, or alternatively by reading it off topographic maps or figures from the original publications. As a last resort, we estimated the elevation of samples from the Digital

171 Elevation Model (DEM), which consists of a mosaic of the 38-03, 38-04, 39-03 and 39-04

172 DEM tiles available from the CGIAR-CSI SRTM $90 \mathrm{~m}$ database (http://srtm.csi.cgiar.org). 
173 All numerical data fields in the database (coordinates, altitude, age, etc.) carry a degree of 174 uncertainty that varies between publications. For instance, the relative standard errors 175 affecting the AFT and ZFT ages used in this paper vary between 2.2 and $51.6 \%$ (average: $17611.6 \%$ ) for the former, and between 0.7 and $23.3 \%$ (average $8.0 \%$ ) for the latter.

\section{Methods}

179 We have developed three joint approaches to take advantage of the high spatial density of 180 fission-track ages in the Western Alps. First, we interpolated AFT and ZFT ages (Figures 3-a 181 and 3-b); second, we calculated cooling and exhumation rates using samples dated with both 182 methods; and third, we constructed isoage surfaces. The latter were used to infer histories of 183 exhumation rates for different areas of the Western Alps between 13.5 and 2.5 Ma.

\subsection{Maps of interpolated ages / track lengths}

186 Using the natural-neighbor interpolation tool provided by the ESRI-ArcMap9 ${ }^{\text {tm }}$ GIS, we 187 created two maps of 635 AFT ages and 296 ZFT ages covering the Western Alps (Figures 3-a 188 and 3-b). For this interpolation, we selected points from the database following three criteria: 189 (1) ages in sedimentary rocks should be reset; (2) samples should be from the surface; and (3) 190 points with non-unique ages are discarded. No potentially arbitrary constraints such as 191 tectonic boundaries or elevation corrections were used in this initial interpolation. The choice 192 of a natural-neighbor interpolator is justified by its conservative properties, resulting in 193 finding at each pixel of the map a weighted average of the neighborhood data points without 194 introducing artefacts (Watson, 1999). However, as we could not introduce a maximum 195 distance of interpolation, localities within the inner Alpine arc are often interpolated between 196 data points located very far apart, at two extremities of the arc. Figure 3-c shows a map of 258 197 mean AFT lengths, interpolated in the same manner as the ages. 


\subsection{Exhumation rates calculated from paired ZFT and AFT ages}

200 We extracted from the database a subset of 143 samples with paired AFT and ZFT ages, 201 following the requirements that (1) they are surface samples; (2) both AFT and ZFT ages are 202 younger than $35 \mathrm{Ma}$ (i.e., Alpine cooling ages); (3) AFT and ZFT ages differ by at least 1.6 203 Myr (an empirical limit set by convergence problems for smaller age differences in the 204 numerical code used); finally (4) points with non-unique ages are discarded. The 143 age 205 pairs offer the opportunity to estimate two successive average exhumation rates: an initial rate 206 during the time between closure of the ZFT and AFT thermochronometers, and a final rate for 207 the time since closure of the AFT system. We used a modified version of the one-dimensional model of Brandon et al. (1998) to calculate iteratively the depth of closure of the ZFT and

209 AFT systems, and then calculate exhumation rate from the value of closure depth and age.

210 This model takes into account the advective perturbation of a steady-state geotherm by 211 exhumation, as well as the dependence of closure temperature on cooling rate (e.g., Dodson 212 1973). It does not, however, include 2-D or 3-D effects such as non-vertical rock-particle 213 paths, spatial variation in geothermal gradient or topographic effects. We have adapted the 214 Brandon et al. (1998) model to simultaneously estimate closure temperatures and depths for 215 both the ZFT and AFT systems (cf. Braun et al., 2006 and van der Beek et al., 2006 for 216 details), using values for the kinetic parameters as estimated by Brandon et al. (1998): AFT: $\mathrm{E}_{\mathrm{a}}=186.4 \mathrm{~kJ} \mathrm{~mol}^{-1}, \mathrm{D}_{0} / \mathrm{a}^{2}=3.64 \times 10^{10} \mathrm{~s}^{-1} ; \mathrm{ZFT}: \mathrm{E}_{\mathrm{a}}=208.2 \mathrm{~kJ} \mathrm{~mol}^{-1}, \mathrm{D}_{0} / \mathrm{a}^{2}=3.70 \times 10^{6} \mathrm{~s}^{-1}$.

218 Other parameter values used in the model are: surface temperature $\mathrm{T}_{\mathrm{s}}=15-(6 \times$ elevation $219(\mathrm{~km}){ }^{\circ} \mathrm{C}$, initial (non-perturbed) geothermal gradient $\mathrm{G}=25^{\circ} \mathrm{C} \mathrm{km}^{-1}$, model thickness $\mathrm{L}=25$ $220 \mathrm{~km}$, thermal diffusivity $\kappa=25 \mathrm{~km}^{2} \mathrm{Myr}^{-1}$. The model predicts initial and final exhumation 221 rates that are consistent with both ages; the ratio between the final and initial rates indicates 222 whether the average exhumation rate accelerated or decelerated after closure of the AFT 
system. An interpolated map of this ratio is plotted in Figure 4. Absolute values of predicted exhumation rates are affected by the assumed initial geothermal gradient, which is largely unknown and may vary spatially. However, the ratio between final and initial rates is not sensitive to this parameter, providing the geothermal gradient does not change through time, other than through advective perturbation.

\subsection{Reconstruction of isoage surfaces}

Apatite fission-track isoage surfaces join all rocks predicted to have cooled through the AFT closure temperature at the same time (Figure 5). They are obtained by interpolation in map view between the elevations of points having the same AFT age. Providing the assumption that the depth of the AFT closure isotherms is only moderately affected by changes in exhumation rate, the latter can be estimated using the vertical distance between two successive isoage surfaces. In this respect, isoage surfaces may be viewed as a 3-D generalization of the 1-D age-elevation profile concept, allowing the same information on denudation history to be extracted on a regional scale and potentially recording spatial variations in denudation rates through time.

Regional variability in geothermal gradient, cooling history and / or apatite annealing kinetics may cause the closure temperature and depth to vary spatially between samples from different tectonic units, thus potentially imposing secondary effects on the spatial variation in elevation of isoage surfaces. However, as for age-elevation profiles, the denudation rate inferred from the elevation difference between successive isoage surfaces is independent of the absolute closure temperature and depth, as long as these remain constant through time. Temporal variations in exhumation rates may affect the AFT closure temperature (Dodson, 1973) as well as the geometry of near-surface isotherms (e.g., Braun, 2002; Stüwe et al., 1994). These 
two factors tend respectively toward over- or under-estimation of the exhumation rate in the case of an increase in exhumation rate. Nevertheless, the characteristic diffusive timescales are rather large (e.g., Braun et al., 2006) so that these variations will be relatively small over the 1 Myr time span separating two isoage surfaces. In any case, the latter effect significantly outweighs the former (e.g., Braun et al., 2006), so that estimated exhumation rates during a period of increase before reaching a thermal steady-state are likely to be minimum estimates.

\subsubsection{Production of arrays of isoage points}

256 The most obvious way to obtain $\mathrm{x}, \mathrm{y}, \mathrm{z}$ coordinates of isoage points is to use the elevation of isoage contours, which, by definition, are the lines of intersection between isoage surfaces and the Earth's surface. We extracted the elevation of each isoage contour traced on the maps of interpolated AFT ages (Figure 3-a) by projection on the Digital Elevation Model (DEM). The spatial resolution of the DEM $(90 \mathrm{~m})$ is much higher than the resolution of the isoage contours

261 (controlled by interpolated points often separated by several kilometers). Therefore, the elevation of any segment of an isoage contour has a high pixel-to-pixel variability (or noise) due to the short-wavelength topography sampled. Nevertheless, the average local value should accurately reflect the elevation of the intersection between an isoage surface and the topography.

We added a second series of isoage points to the array, based on local estimates of AFT ageelevation relationships (AER) in the neighborhood of data points where the correlation between these two parameters was statistically significant (Figure 6). The aim is to document areas where the AER are well correlated and use them to interpolate the elevation of isoage surfaces. We used a subset of 660 AFT samples with an age younger than $35 \mathrm{Ma}$ for this approach. Sample elevation values that had to be derived from the DEM were found to 
273 introduce too much noise in the calculation of regression coefficients for age-elevation

274 relationships and were therefore rejected. We did include, however, data points with non-

275 unique ages, as they comply with the requirements to estimate age-elevation relationships.

276 The condition of sample ages younger than $35 \mathrm{Ma}$ aims to avoid introducing samples that are

277 manifestly partially reset, such as those with Mesosoic ages from the Southern Alps (cf.

278 Figure 3-a), into the calculation of AER regression lines.

280 For our semi-automated AER analysis, we first selected the neighbors of every point in the 281 database, included in a circle of increasing radius (from 3 to $15 \mathrm{~km}$ ). For every selection 282 containing more than 4 points, we calculated a regression line between age (dependent 283 variable) and elevation (independent variable), together with its correlation coefficient. The 284 AER was judged significant and was retained if the correlation coefficient for the regression 285 was higher than the critical Pearson's product-moment coefficient at $95 \%$ confidence level 286 for the appropriate number of degrees of freedom (cf. Figures 6-b and 6-c). When the initial 287 selection around a data point ( $3 \mathrm{~km}$ radius) failed this statistical test, we incrementally 288 increased the search radius by $2 \mathrm{~km}$ steps to a maximum of $15 \mathrm{~km}$. This maximum presents a 289 characteristic distance between adjacent valleys: for larger search radii, the samples selected 290 may belong to adjacent valleys with distinct exhumation histories. We used the regression 291 equations calculated from the set of points selected within the smallest successful search 292 radius possible, because they constitute the closest equivalent to a vertical profile and 293 therefore carry the smallest risk for the AER to be affected by either large-scale tilting (Rahn 294 et al., 1997) or the deflection of isotherms in large Alpine valleys (e.g., Braun, 2002; Stüwe et 295 al., 1994). 
297 The local AER is described by the simple linear equation $z=A_{0}+\left(A_{1} \times t\right)$, where $A_{0}$ is the 298 elevation of the zero-age intercept, and $A_{1}$ is the slope of the AER (with $z$ : elevation [m]; $t$ : 299 age [Ma]). Statistically significant AERs extracted from the data are used to interpolate the 300 elevations of isoage surfaces at the location of the center of the search radius, limiting the 301 extrapolation to between 1 Myr before the oldest and 1 Myr after the youngest age in the 302 neighborhood selection. This limitation is imposed in order to avoid extrapolating age303 elevation trends into periods during which they are not locally documented. In case of a 304 slightly kinked AER (i.e. change in exhumation rate with time), the slope $A_{1}$ would be 305 averaged; if the kink is more pronounced the linear correlation coefficient will be insignificant 306 and the neighborhood selection rejected. Given that this study is aimed at testing for changing 307 exhumation rates through time, the rejection of kinked AERs in the generation of isoage data 308 points is conservative, and will downplay any signal.

\subsubsection{Interpolation of isoage point arrays}

311 We constructed isoage surfaces by natural-neighbor interpolation applied to the elevations of 312 the points constituting each isoage array (Figure 6d). In order to remove unconstrained parts 313 of the surfaces, which have been interpolated far from any point of the isoage arrays, a mask 314 is applied at $15 \mathrm{~km}$ around the point arrays. The oldest isoage surfaces have been eroded from 315 large parts of the study area, while the youngest surfaces remain buried in other areas, 316 resulting in a heterogeneous scatter of each array of isoage points. The result is a series of 317 thirteen maps showing isoage surfaces between 14 and 2 Ma where they can be reconstructed 318 with reasonable accuracy; a representative selection of six isoage surfaces is reported in 319 Figure 7. 


\subsection{Estimation of exhumation rates}

322 The vertical distance between two isoage surfaces corresponds, in principle, to the amount of 323 exhumation during the time period separating them, with the same caveats that apply to the 324 interpretation of 1-D age-elevation profiles, notably the effect of topography on the AER 325 slope (Braun, 2002). In the crystalline massifs of the Western Alps, geomorphic data suggest 326 a significant recent increase in relief (e.g., Champagnac et al., 2007; van der Beek and 327 Bourbon, 2008) so that we expect topographic effects to be limited and the distance between 328 successive isoage surfaces to provide a reliable estimate of exhumation.

330 After being clipped by the $15 \mathrm{~km}$ mask, each isoage surface covers only a limited portion of 331 the Western Alps, and two successive surfaces are never completely superposed. Therefore, it 332 is not possible to calculate the total volume exhumed over the entire surface of the Western 333 Alps during any time period. Instead, we focused on eight specific areas characterized by 334 several million years of continuous isoage surface coverage (Figure 8).

336 The difference in elevation between successive isoage surfaces is calculated for all $1.2 \mathrm{~km}^{2}$ 337 pixels of each study area and the average distance constitutes our estimate of exhumation 338 during the corresponding time period. Some pixels show negative differences, i.e. the younger 339 isoage surface lies above the older one. These correspond either to artefacts introduced by our 340 treatment of the data or to local areas of strong recent relief decrease. We decided to exclude 341 these pixels from our calculation of the average distance between isoage surfaces, as two 342 isoage surfaces cannot cross each other in an exhuming massif. To illustrate pixel value 343 distributions, Figure 9 presents the values measured between the surfaces aged 5 and 4 Ma for 344 the Mont Blanc area. Plotted against time, the average distances between isoage surfaces 345 enable quantifying the temporal evolution of exhumation rates over each area (Figure 10). 
347 Samples that underwent slow cooling through the partial annealing zone may lead to apparent 348 AERs that do not correspond to the exhumation rate (e.g., Gallagher et al., 1998). The mean 349 track lengths can be used to monitor whether this is the case, as samples that cooled slowly 350 through the partial annealing zone are characterized by mean track length $\leq \sim 12.5 \mu \mathrm{m}$. Most 351 areas covered by our constructed isoage surfaces are characterized, in contrast, by sample 352 mean track length $\geq 13 \mu \mathrm{m}$ (compare Figures 3-c and 8), with the exception of the Bergell and 353 the Aar-Leventina (areas 1 and 6 in Figure 8).

\section{Results}

\subsection{Main features of the fission-track age patterns}

Young AFT ages $(<10 \mathrm{Ma})$ appear in the axial region of the Western Alps (Figure 3-a) and particularly over the Argentera, Ecrins - Mont-Blanc, and Aar External Crystalline Massifs. Very young ages $(<5 \mathrm{Ma})$ are also found in the Chur region, between the eastern Aar and the

360 Silvretta nappe, and in the western Lepontine dome, east of the Simplon fault. In contrast, the 361 internal crystalline massifs (Gran Paradiso, Dora Maira) as well as the Austroalpine units are 362 characterized by early Miocene or older AFT ages (> $10 \mathrm{Ma})$. An inverse relationship 363 between AFT age and mean track length appears, with ages $<10$ Ma generally characterized 364 by mean track length $>13 \mu \mathrm{m}$ (compare Figures 3 -a and 3-c). The only exception to this 365 pattern is a band of short mean track lengths extending from the central Aar massif to the SSE 366 (Figure 3-c). Young ZFT ages $(<15 \mathrm{Ma})$ characterize the Aar, Mont-Blanc, Belledonne and 367 Lepontine massifs (Figure 3-b). Extensive regions of both the external and internal parts of 368 the orogen show early Alpine ZFT ages (20-35 Ma), whereas two orogen-parallel bands (an 369 external band covering the frontal parts of the Mont-Blanc and Aar massifs and an internal 
band running from the eastern Ecrins across the Southern Alps) show ZFT ages that were not

371 reset by the Alpine orogeny (i.e., ZFT age $\geq 35 \mathrm{Ma}$ ).

The AFT and ZFT age patterns run parallel to two major Alpine tectonic lineaments: the

Penninic thrust, bordering the External Crystalline Massifs, and the Simplon fault. Both areas show younger ages in their footwalls (Figures 3-a and 3-b), which suggests that a component of tectonic exhumation may affect the age patterns, as previously suggested in more local studies (Fügenschuh and Schmid, 2003; Seward and Mancktelow, 1994; Tricart et al., 2007).

\subsection{Variation in exhumation rate from paired AFT and ZFT ages}

380 A pattern of recent accelerated exhumation, dominantly affecting the external side of the belt 381 (and the External Crystalline Massifs in particular), is evidenced in Figure 4. This map 382 demonstrates an overall acceleration in exhumation rate along the northern and western 383 borders of the orogen, since these areas crossed the AFT closure temperature of $\sim 120{ }^{\circ} \mathrm{C}$.

384 AFT ages in the region showing accelerated denudation are mostly $\leq 8 \mathrm{Ma}$ (compare Figures 385 3-a and 4). However, exhumation rates used in this ratio calculation are average values for 386 initial cooling between the ZFT and AFT closure temperatures and final cooling between the 387 AFT closure temperature and the surface, and do not enable us to resolve when the 388 acceleration occurred.

\subsection{Description of isoage surfaces}

391 The elevation of isoage surfaces generally increases with age (see legend on each map of 392 Figure 7), which is consistent with the assumption that isoage surfaces are mainly controlled 393 by the effect of denudation on isotherms (Figure 5). The overall shape of the isoage surfaces 394 is that of arcuate domes, the axes of which are roughly superposed with the External 
Crystalline Massifs (Aar, Mont-Blanc and Ecrins, see Figure 2) for the younger surfaces, and 396 with more internal massifs (Lepontine Alps, Dent-Blanche) for older surfaces. Young isoage 397 surfaces are defined mostly by points from high-relief areas with young fission-track ages in 398 the valleys, whereas old isoage surfaces are controlled by locally old fission-track ages 399 encountered on topographic peaks and the elevation of isoage contours in the periphery of the 400 orogen.

\subsection{Spatial and temporal evolution of exhumation rates}

403 The difference in elevation of AFT isoage surfaces was used to estimate exhumation rates 404 between 13.5 and 2.5 Ma over the Western Alps (Figures 7-10). Comparing curves of 405 exhumation rate against time for different sub-areas (Figure 10) highlights a series of eight 406 overlapping segments from 9.5 to $2.5,9.5$ to $4.5,13.5$ to 10.5 and 13.5 to $4.5 \mathrm{Ma}$, which all 407 share a similar trend. The estimates of exhumation rate vary between 200 and $700 \mathrm{~m} / \mathrm{Myr}$, 408 with an acceleration centered around $5 \mathrm{Ma}$, which is in surprisingly good agreement with perialpine sedimentation rates and inferred alpine denudation rates reported by Kuhlemann and 410 co-workers (Kuhlemann, 2000; Kuhlemann et al., 2002). While we are mostly interested in

411 the pattern of denudation rates at the orogen scale, regional variations in the exhumation 412 history demonstrate the localization of denudation (Figure 10). The exhumation rates 413 estimated in the Bergell and Valais-Sesia areas (curves 1 and 2) are similar and indicate a 414 denudation rate of $300 \mathrm{~m} / \mathrm{Myr}$ between 13.5 and $10.5 \mathrm{Ma}$. The Ecrins and Mont-Blanc 415 massifs (curves 3 and 4) share a similar pattern of increase in exhumation rate between 5.5 416 and $4.5 \mathrm{Ma}$, with recent rates reaching $500 \mathrm{~m} / \mathrm{Myr}$. Further east, the Aar-Leventina area 417 (curve 6) shows a slightly earlier increase in exhumation rate ( $\sim \mathrm{Ma})$. However, the 418 occurrence of short mean track lengths in the Aar-Leventina and the Bergell areas (cf. section 419 4.4) may lead us to overestimate recent exhumation. In contrast, the onset of the acceleration 
420 in the Simplon and Chur areas (curves 5 and 7) appears to be younger than $3.5 \mathrm{Ma}$, with 421 recent denudation rates reaching over $600 \mathrm{~m} / \mathrm{Myr}$. The sub-area with the longest continuous coverage in isoage surfaces (area 8 on Figure 8) combines a suite of small areas in the Western Alps. The values of exhumation rate it provides between 13.5 and $4.5 \mathrm{Ma}$ (curve 8 on Figure 10) are included within the range of the seven other sub-areas.

\section{Discussion}

\subsection{Conditions of use of isoage surfaces}

428 The use of isoage surfaces to calculate exhumation rates through time requires that the 429 surfaces have not been significantly deformed. Therefore, actively deforming thrust belts 430 would need to be treated with caution. Locations undergoing relief reduction are also to be 431 avoided because age-elevation relationships would provide overestimates of exhumation rates 432 (Braun, 2002). The optimal conditions are met in orogens where relief is either steady or 433 increasing, and tectonic activity is insufficient to significantly deform the isoage surfaces. The 434 Western Alps are a successful candidate because relief appears to have increased recently due 435 to glaciations (Champagnac et al., 2007; van der Beek and Bourbon, 2008), whereas present436 day tectonic activity is limited (e.g., Calais et al., 2002). Moverover, the European Alps are 437 covered by an exceptional density of existing AFT ages, allowing us to use the approach 438 developed here.

\subsection{Errors affecting exhumation rate calculations}

441 Several types of error potentially affect the calculation of exhumation rates from isoage 442 surfaces: (1) uncertainties affecting the ages, elevations and coordinates of samples in the 443 database used to compute isoage surfaces, (2) heterogeneous scatter of the interpolated data 444 points, and (3) geological factors such as the composition of apatites (defining their precise 
445 closure temperature) and spatial or temporal variations in relief and geothermal gradient.

446 While errors of type 1 can be estimated on a sample per sample basis, propagating these into 447 an uncertainty in isoage surface elevation cannot be done rigorously, although a Monte Carlo 448 approach in which the surfaces are created thousands of times while varying the input data 449 within error could be envisaged. Whereas uncertainties of type 2 (role of sampling density and 450 scatter) are generally assessed using kriging techniques, these are limited for geological 451 applications because of strong assumptions on spatial continuity and statistics of the data. 452 Alternatively such errors may be evaluated using calculation-intensive boot-strap techniques. 453 Uncertainties of type 3, however, are practically impossible to quantify. Moreover, the weight 454 of these three types of errors within the final uncertainty in exhumation rates is unknown. 455 Therefore, we chose to present the estimates of exhumation rates as such, without the addition 456 of an inherently partial and, therefore, misleading error.

\subsection{Comparison between exhumation rates and the volume of sediment deposited}

\section{through time}

460 The exhumation rates calculated from the AFT isoage surfaces over the Western Alps (Figure 461 10) are of the same order $(200-600 \mathrm{~m} / \mathrm{Myr})$ as those calculated from the sedimentary record 462 (Kuhlemann, 2000; Willett et al., 2006). They are also, more expectedly, comparable with 463 denudation rates obtained from local thermochronological studies (e.g., Michalski and Soom, 464 1990; Schär et al., 1975; Schlunegger and Willett, 1999; Tricart et al., 2007). Thus, both the 465 sedimentary record and the in-situ thermochronological record show a similar increase in 466 exhumation rates around $5 \mathrm{Ma}$. However, the thermochronometric estimates of denudation 467 rates are overall slightly higher than those obtained from the sedimentary record (Figure 10). 468 This small offset may be explained by the fact that areas with the most complete isoage 469 surface coverage, which are used in the calculations, are biased toward the more rapidly 
eroding massifs with young AFT ages in the valleys, and therefore do not constitute a representative sampling of the entire Western Alps. Other explanations could be an overestimation of exhumation rates obtained from age-elevation relationships (Braun, 2002) or a general bias in the calculation of sediment volume, which, for instance, does not take chemical weathering or sediment recycling into account.

\subsection{Possible causes for increased recent exhumation}

Over the last $14 \mathrm{Myr}$, the shift of the apex of isoage surface domes through time from the inner Alps to the External Crystalline Massifs (Figure 7) suggests a shift of the most actively exhuming regions during late Miocene and Pliocene times. This idea is in agreement with the map of the ratio of final / initial exhumation rates (Figure 4), where acceleration of exhumation is observed after AFT closure in the External Crystalline Massifs..

Within this general frame, we observe a broad increase in exhumation rate in the Western Alps centered around $5 \mathrm{Ma}$, with local variations in the timing of this increase (Figure 10). Assuming that these variations are significant compared to the unquantified uncertainty, they suggest that the rise in Alpine denudation described as happening around $5 \mathrm{Ma}$ (e.g.

Cederbom et al., 2004; Kuhlemann, 2000), actually varied considerably, taking place between 6.5 and 2.5 Ma depending on local tectonic and structural conditions. A clear expression of regional diversity within a general trend of exhumation increase is found in the Simplon and Chur areas (Figures 8 and Figure 10). The resent surge in exhumation rates in these areas can be linked spatially to present-day high rock-uplift rates in the western and eastern Aar massif (e.g., Persaud and Pfiffner, 2004). Although a significant part of present-day rock uplift rates could be due to the isostatic response to erosional unloading (Champagnac et al., 2007; Schlunegger and Hinderer, 2001), this spatial link may suggest that these two locations are 
characterized by high rock uplift rates since at least the time of AFT closure. Furthermore, this pattern suggests that current exhumation of the Aar massif is concentrated on its western and eastern borders, and has been so for several million years.

Based on the approximate temporal coincidence between Mio-Pliocene acceleration of exhumation in the Western Alps, and the closure of the Panama isthmus and subsequent reorganization of Atlantic Ocean currents, Cederbom et al. (2004) proposed that the increase in exhumation around $5 \mathrm{Ma}$ was externally controlled by increased precipitation over Europe. An alternative, and more global mechanism, is that the increased variability of climate witnessed by the ocean oxygen isotope record forced accelerated erosion rates, although the data suggest that this happened between 4 and 3 Ma (e.g., Molnar, 2004; Zhang et al., 2001). Although this explanation remains difficult to confirm, it is seducing as a cause on a global, or at least a continental, scale could explain the simultaneous increase in exhumation in other orogens (e.g., Molnar, 2004; Zhang et al., 2001). Uplift of the Western Alps followed by widespread exhumation may also be controlled by a deep-seated event such as slab detachment; however, no evidence exists to tie such an event down at this particular time.

\section{Conclusions}

Our analysis of the complete fission-track thermochronology database in the Western Alps leads to the following general conclusions:

1) Although different regions of the Western Alps show a variable absolute amount of exhumation since 13.5 Ma, they share a common trend of doubling in exhumation rates at approximately $5 \mathrm{Ma}$. Providing assumptions on error values, it is possible to distinguish between areas where the rise in Alpine denudation took place at different periods within a 6.5 to 2.5 Ma time frame. 
520 2) The overall consistency between estimated denudation rates using sediment volumes

521 (Kuhlemann, 2000), and bedrock thermochronology (this study) demonstrates that, although

522 both records are fragmentary and error-prone, they are appropriate to describe the general

523 exhumation history at the orogen scale since at least 13.5 Ma.

524 3) The maps of zircon and apatite fission-track ages share a pattern of young ages over an arc

525 linking the External Crystalline Massifs, as well as in the area of the Lepontine Alps,

526 suggesting that these areas underwent the strongest recent denudation in the Western Alps.

527 The observed longer mean AFT lengths in the areas with young fission track ages further 528 supports this conclusion.

529 4) This pattern fits with the trend of accelerated exhumation rates calculated from samples 530 with paired zircon and apatite fission-track ages. This trend indicates that most of the Western 531 Alps, in particular the external side of the arc, was on average exhumed faster after AFT 532 closure than between the times of ZFT and AFT closure.

\section{Acknowledgements}

535 This study is supported by an INSU-CNRS "Reliefs de la Terre" program grant to PvdB. AV 536 is supported by a University of Edinburgh $\mathrm{PhD}$ teaching scholarship and an international 537 student mobility (MIRA) grant of the Rhône-Alpes region. We are grateful to M. Ford and D. 538 Seward for permission to use unpublished AFT ages. L. Keller, P. Leloup, S. Schwartz and P. 539 Tricart kindly provided complementary details on their published material. The manuscript 540 benefited from thorough and constructive reviews by Kerry Gallagher and an anonymous 541 reviewer. 


\section{References}

Becker, A., 2000. The Jura Mountains - An active foreland fold-and-thrust belt? Tectonophysics. 321, 381-406.

Bernet, M., Zattin, M., Garver, J.I., Brandon, M.T., Vance, J.A., 2001. Steady-state exhumation of the European Alps. Geology. 29, 35-38.

Bigot-Cormier F., 2002. La surrection du massif cristallin externe de 1'Argentera (FranceItalie) et ses relations avec la déformation pliocène de la marge nord-Ligure : arguments thermochronologiques (traces de fission), géomorphologiques et interprétations de sismique marine. PhD Thesis, University of Nice, France, $352 \mathrm{p}$.

Bistacchi, A., Massironi, M., 2000. Post-nappe brittle tectonics and kinematic evolution of the north-Western Alps: an integrated approach. Tectonophysics. 327, 267-292.

Bogdanoff, S., Michard, A., Mansour, M., Poupeau, G., 2000. Apatite fission track analysis in the Argentera massif: evidence of contrasting denudation rates in the External Crystalline Massifs of the Western Alps. Terra Nova. 12, 117-125.

Brandon, M.T., Roden-Tice, M.K., Garver, J.I., 1998. Late Cenozoic exhumation of the Cascadia accretionary wedge in the Olympic Mountains, Northwest Washington State. Geological Society of America Bulletin. 110, 985-1009.

Braun, J., 2002. Quantifying the effect of recent relief changes on age-elevation relationships. Earth and Planetary Science Letters. 200, 331-343.

Braun, J., van der Beek, P., Batt, G., 2006. Quantitative Thermochronology: Numerical methods for the interpretation of thermochronological data. Cambridge University Press, Cambridge. 270 p.

Bürgi, A., Klötzli, U., 1990. New data in the Evolutionary History of the Ivrea Zone (Northern Italy). Bulletin der Vereinigung Schweizerische Petroleum-Geologen und Ingenieur. 56, 49-69. 
Calais, E., Nocquet, J.-M., Jouanne, F., Tardy, M., 2002. Current strain regime in the Western Alps from continuous Global Positioning System measurements, 1996-2001. Geology. 30, 651-654.

Carpéna, J., 1992. Fission track dating of zircon: zircons from Mont Blanc Granite (FrenchItalian Alps). The Journal of Geology. 100, 411-421.

Carpéna, J., Caby, R., 1984. Fission track evidence for late Triassic oceanic crust in the French Occidental Alps. Geology. 12, 108-111.

Carpéna, J., Pognante, U., Lombardo, B., 1986. New constraints for the timing of the Alpine metamorphism in the internal ophiolithic nappes from the Western Alps as inferred from fission track data. Tectonophysics. 127, 117-127.

Cederbom, C.E., Sinclair, H.D., Schlunegger, F., Rahn, M.K., 2004. Climate-induced rebound and exhumation of the European Alps. Geology. 32, 709-712.

Champagnac, J.D., Molnar, P., Anderson, R.S., Sue, C., Delacou, B., 2007. Quaternary erosion-induced isostatic rebound in the Western Alps. Geology. 35, 195-198.

Ciancaleoni, L., 2005. Deformation processes during the last stages of the continental collision: the brittle-ductile fault systems in the Bergell and Insubric areas (Eastern Central Alps, Switzerland - Italy). PhD Thesis, University of Neuchâtel, Switzerland, $202 \mathrm{p}$.

Debelmas, J., Lemoine, M., 1970. The Western Alps: Paleogeography and Structure. EarthScience Reviews. 6, 221-256.

Dodson, M.H., 1973. Closure temperature in cooling geochronological and petrological systems. Contributions to Mineralogy and Petrology. 40, 259-274.

Ehlers, T.A., Farley, K.A., Rusmore, M.E., Woodsworth, G.J., 2006. Apatite (U-Th)/He signal of large-magnitude accelerated glacial erosion, southwest British Columbia. Geology. 34, 765-768. 
Flisch, M., 1986. Die Hebungsgeschichte der oberostalpinen Silvretta-Decke seit der mittleren Kreide. Bulletin der Vereinigung Schweizerische Petroleum-Geologen und Ingenieur. 53, 23-49.

Fügenschuh, B., Loprieno, A., Ceriani, S., Schmid, S.M., 1999. Structural analysis of the Subbriançonnais and Valais units in the area of Moûtiers, Savoy, Western Alps: paleogeographic and tectonic consequences. International Journal of Earth Sciences. 88, 201-218.

Fügenschuh, B., Schmid, S.M., 2003. Late stages of deformation and exhumation of an orogen constrained by fission track data: A case study in the Western Alps. Geological Society of America Bulletin. 115, 1425-1440.

Gallagher, K., Brown, R., Johnson, C., 1998. Fission track analysis and its applications to geological problems. Annual Review of Earth and Planetary Sciences. 26, 519-572.

Gallagher, K., Brown, R., 1999. Denudation and uplift at passive margins: the record on the Atlantic margin of southern Africa. Philosophical Transactions of the Royal Society of London. 357, 835-859.

Giger, M., 1991. Geochronologische und petrographische Studien an Geröllen und Sedimenten der Gonfolite Lombarda Gruppe (Südschweiz und Norditalien) und ihr Vergleich mit dem alpinen Hinterland. PhD Thesis, University of Bern, Switzerland, $227 \mathrm{p}$.

Hinderer, M., 2001. Late Quaternary denudation of the Alps, valley and lake fillings and modern river loads. Geodinamica Acta. 14, 231-263.

Homewood, P., Allen, P.A., Williams, G.D., 1986. Dynamics of the Molasse Basin of western Switzerland, in: Allen, P.A., Homewood, P. (Eds.), Foreland basins. International Association of Sedimentologists Special Publication. 8, 199-217. 
Hunziker, J., Desmons, J., Hurford, A.J., 1992. Thirty-two years of geochronological work in the Central and Western Alps: a review on seven maps. Mémoire de Géologie 13, Lausanne, 59 p.

Hurford, A.J., 1986. Cooling and uplift patterns in the Lepontine Alps, South Central Switzerland and an age of vertical movement of the Insubric fault line. Contributions to Mineralogy and Petrology. 92, 413-427.

Hurford, A.J., 1991. Uplift and cooling pathways derived from fission track analysis and mica dating: a review. Geologische Rundschau, 80, 349-368.

Hurford, A.J., Green, P.F., 1982. A user's guide to fission track dating calibration. Earth and Planetary Science Letters. 59, 343-354.

Hurford, A.J., Hunziker, J.C., 1985. Alpine cooling history of the Monte Mucrone eclogites. Schweizerische Mineralogische und Petrographische Mitteilungen. 65, 325-334.

Hurford, A.J., Hunziker, J.C., 1989. A revised thermal history for the Gran Paradiso massif. Schweizerische Mineralogische und Petrographische Mitteilungen. 69, 319-329.

Hurford, A.J., Hunziker J.C., Stöckhert, B., 1991. Constraints on the late thermotectonic evolution of the Western Alps: Evidence for episodic rapid uplift. Tectonics. 10, 758-769.

Keller, L.M., Hess, M., Fügenschuh, B., Schmid, S., 2005. Structural and metamorphic evolution of the Camughera-Moncucco, Antrona and Monte Rosa units southwest of the Simplon line, Western Alps. Eclogae geologicae Helvetiae. 98, 19-49.

Knaus, A., 1990. Apatit-Spaltspurendatierungen in Rätikon (Arosazone, Östalpen), part 1. Diploma Thesis, University of Tübingen, Germany, 60 p.

Kuhlemann, J., 2000. Post-collisional sediment budget of circum-Alpine basins (Central Europe). Memorie di Scienze Geologiche, Padova. 52, 1-91. 
Kuhlemann, J., Frisch, W., Szekely, B., Dunk1, I., Kazmer, M., 2002. Post-collisional sediment budget history of the Alps: tectonic versus climatic control. International Journal of Earth Sciences. 91, 818-837.

Lelarge, L., 1993. Thermochronologie par la méthode des traces de fission d'une marge passive (Dome de Ponta Grossa, SE Brésil) et au sein d'une chaîne de collision (zone externe de l'arc alpin, France). PhD Thesis, University of Grenoble, France, $252 \mathrm{p}$.

Leloup, P.H., Arnaud, N., Sobel, E.R., Lacassin, R., 2005. Alpine thermal and structural evolution of the highest external crystalline massif: The Mont Blanc. Tectonics. 24, TC4002, doi:10.1029/2004TC001676.

Malusa, M.G., Polino, R., Zattin, M., Bigazzi, G., Martin, S., Piana, F., 2005. Miocene to Present differential exhumation in the Western Alps: Insights from fission track thermochronology. Tectonics. 24, TC3004, doi:10.1029/2004TC001782.

Michalski, I., Soom, M., 1990. The Alpine thermo-tectonic evolution of the Aar and Gotthard massifs, Central Switzerland: Fission track ages on zircons and apatites and K-Ar mica ages. Schweizerische Mineralogische und Petrographische Mitteilungen. 70, 373-387.

Molnar, P., 2004. Late Cenozoic Increase in Accumulation Rates of Terrestrial Sediment: How Might Climate Change Have Affected Erosion Rates? Annual Review of Earth and Planetary Sciences. 32, 67-89.

Morris, R.G., Sinclair, H.D., Yelland, A.J., 1998. Exhumation of the Pyrenean orogen: implications for sediment discharge. Basin Research. 10, 69-85.

Oberhänsli, R., Bousquet, R., Engi, M., Goffé, B., Gosso, G., Handy, M., Höck, V., Koller, F., Lardeaux, J.-M., Polino, R., Rossi, O.P., Schuster, R., Schwartz, S., Spalla, I., 2004. Metamorphic structure of the Alps, 1:1 000 000, Commission for the 

Gesellschaft. 149.

668 Pawlig, S., 2001. Geological Evolution of the Monte Rosa: Constraints from Geochronology 669 faults, seismicity and surface uplift. Tectonophysics. 385, 59-84.

Pieri, M., Groppi, G., 1981. Subsurface geological structure of the Po Plain. Consiglio Nazionale delle Richerche, Pubblicazione 414 del Progetto Finalizzato Geodinamica, 23 p.

Rahn, M.K., 1994. Incipient metamorphism of the Glarus Alps: Petrology of the Taveyanne Greywacke and fission track dating. PhD Thesis, University of Basel, Switzerland, 209 p.

Rahn, M.K., Hurford, A.J., Frey, M., 1997. Rotation and exhumation of a thrust plane: apatite fission track data from the Glarus thrust, Switzerland. Geology. 25, 599-602.

Raymo, M.E., Ruddiman, W.F., 1992. Tectonic forcing of late Cenozoic climate. Nature. 359, 117-122.

Ring, U., Brandon, M.T., Willett, S.D., Lister, G.S., 1999. Exhumation processes, in: Ring, U., Brandon, M.T., Lister, G.S., Willett, S.D. (Eds.), Exhumation Processes: Normal Faulting, Ductile Flow and Erosion. Geological Society, London, Special Publications. 154, 1-27.

Rosenbaum, G., Lister, G.S., 2005. The Western Alps from the Jurassic to Oligocene: spatiotemporal constraints and evolutionary reconstructions. Earth-Science Reviews. 69, 281-306. 
Sabil, N., 1995. La datation par traces de fission : aspects méthodologiques et applications thermochronologiques en contextes alpins et de marge continentale. $\mathrm{PhD}$ Thesis, University of Grenoble, France, 238 p.

Scardia, G., Muttoni, G., Sciunnach, D., 2006. Subsurface magnetostratigraphy of Pleistocene sediments from the Po Plain (Italy): Constraints on rates of sedimentation and rock uplift. Geological Society of America Bulletin. 118, 1299-1312.

Schär, J.P., Reimer, G.M., Wagner, G.A., 1975. Actual and ancient uplift rate in the Gotthard region, Swiss Alps: A comparison between precise levelling and fission track apatite age. Tectonophysics. 29, 293-300.

Schlunegger, F., Hinderer, M., 2001. Crustal uplift in the Alps: why the drainage pattern matters. Terra Nova. 13, 425-432.

Schlunegger, F., Willett, S.D., 1999. Spatial and temporal variations in exhumation of the central Swiss Alps and implications for exhumation mechanisms, in: Ring, U., Brandon, M.T., Lister, G.S., Willett, S.D. (Eds.), Exhumation Processes: Normal Faulting, Ductile Flow and Erosion. Geological Society, London, Special Publications. 154, 157-179.

Schmid, S.M., Fügenschuh, B., Kissling, E., Schuster, R., 2004. Tectonic map and overall architecture of the Alpine orogen. Eclogae geologicae Helvetiae. 97, 93-117.

Schmid, S.M., Pfiffner, O.A., Froitzheim, N., Schönborn, G., Kissling, E., 1996. Geophysicalgeological transect and tectonic evolution of the Swiss-Italian Alps. Tectonics. 15, 1036-1064.

Schwartz, S., 2000. La zone piémontaise des Alpes occidentales : un paléo-complexe de subduction. Arguments métamorphiques, géochronologiques et structuraux. $\mathrm{PhD}$ Thesis, University of Lyon 1, France, 341 p. 
715 Seward, D., Ford, M., Bürgisser, J., Lickorish, H., Williams, E.A., Meckel, L.D.III, 1999.

Preliminary results of fission track analyses in the Southern Pelvoux area, SE France. 3rd Workshop on Alpine Geological Studies, Memorie di Scienze Geologiche Padova. 51, 25-31.

Seward, D., Mancktelow, N.S., 1994. Neogene kinematics of the central and Western Alps: Evidence from fission-track dating. Geology. 22, 803-806.

Soom, M.A., 1990. Abkühlungs- und Hebungsgeschichte der Externmassive und der penninischen Decken beidseits der Simplon-Rhone-Linie seit dem Oligozän: Spaltspurdatierung and Apatit/Zirkon und K-Ar-Datierungen an Biotit/Muskovit (westliche Zentralalpen). PhD Thesis, University of Bern, Switzerland, 64 p.

Steiner, H., 1984. Mineralogisch-petrographische, geochemische und isotopengeologische Untersuchungen an einem Meta-Lamprophyr und seinem granodioritischen Nebengestein (Matorello-Gneis) aus der Maggia-Decke. Schweizerische Mineralogische und Petrographische Mitteilungen. 64, 227-259.

Stephenson, J., Gallagher, K., Holmes, C.C., 2006. Low temperature thermochronology and strategies for multiple samples 2: Partition modelling for 2-D/3-D distributions with discontinuities. Earth and Planetary Science Letters. 241, 557-570.

Stüwe, K., White, L., Brown, R., 1994. The influence of eroding topography on steady-state isotherms. Application to fission track analysis. Earth and Planetary Science Letters. $124,63-74$.

Sue, C., Delacou, B., Champagnac, J.-D., Allanic, C., Tricart, P., Burkhard, M., 2007. Extensional neotectonics around the bend of the Western/Central Alps: an overview. International Journal of Earth Sciences. 96, 1001-1029.

Timar-Geng, Z., Grujic, D., Rahn, M., 2004. Deformation at the Leventina-Simano nappe boundary, Central Alps, Switzerland. Eclogae geologicae Helvetiae. 97, 265-278. 
Trautwein, B., 2000. Detritus provenance and thermal history of the Rhenodanubian flysch zone: mosaicstones for the reconstruction of the geodynamic evolution of the Eastern Alps. Tübinger Geowissenschaftliche Arbeiten 59, 75 p.

Tricart, P., van der Beek, P., Schwartz, S., Labrin, E., 2007 Diachronous late-stage exhumation across the Western Alpine arc: constraints from apatite fission track thermochronology between the Pelvoux and Dora-Maira Massifs. Journal of the Geological Society, London. 163, 1-12.

Trümpy, R., 1960. Paleotectonic evolution of the central and Western Alps. Bulletin of the Geological Society of America 71: 843-908.

van der Beek, P., Bourbon, P, 2008. A quantification of the glacial imprint on relief development in the French Western Alps. Geomorphology in press.

van der Beek, P., Robert, X., Mugnier, J.-L., Bernet, M., Huyghe, P., Labrin, E., 2006. Late Miocene-Recent exhumation of the central Himalaya and recycling in the foreland basin assessed by apatite fission track thermochronology of Siwalik sediments, Nepal. Basin Research. 18, 413-434.

Vance, J.A., 1999. Zircon fission track evidence for a Jurassic (Tethyan) thermal event in the Western Alps. In Fission track Analysis: Theory and Applications. S. Martin, R. Polino Eds. Memorie di Scienze Geologiche, Padova. 51, 473-476.

Viola, G., 2000. Kinematics and timing of the Periadriatic fault system in the Giudicarie region (central-Eastern Alps). PhD Thesis, n 13590, ETH Zürich, Switzerland, 206 p.

Wagner, G.A., Miller, D.S., Jäger, E., 1979. Fission track ages on apatite of Bergell rocks from central Alps and Bergell boulders in Oligocene sediments. Earth and Planetary Science Letters. 45, 355-360. 
764 Wagner, G.A., Reimer, G.M., 1972. Fission track tectonics: The tectonic interpretation of fission track apatite ages. Earth and Planetary Science Letters. 14, 263-268.

766 Wagner, G.A., Reimer, G.M., Jäger, E., 1977. Cooling ages derived by apatite fission track, mica $\mathrm{Rb}-\mathrm{Sr}$ and $\mathrm{K}-\mathrm{Ar}$ dating: the uplift and cooling history of the Central Alps. Memorie di Scienze Geologiche, Padova. 30, 1-27.

769 Watson, D., 1999. The natural neighbor series manuals and source codes. Computers and Geosciences. 25, 463-466.

771 Weh, M., 1998. Tektonische Entwicklung der penninischen Sediment-Decken in Graubünden (Prättigau bis Oberhalbstein). PhD Thesis, University of Basel, Switzerland, 230 p.

773 Willett, S.D., Schlunegger, F., Picotti, V., 2006. Messinian climate change and erosional destruction of the central European Alps. Geology. 34, 613-616.

Zhang, P., Molnar, P., Downes, W.R., 2001. Increased sedimentation rates and grain sizes 2-4 897. 


\section{Figure captions}

781 Figure 1. Evolution of sedimentation rates through time, reconstructed from the preserved 782 volume of sediments originating from the Western and the Eastern Alps, respectively 783 (modified from Kuhlemann et al., 2002).

Figure 2. (a) Simplified geologic map of the Western Alps (modified from Schmid et al., 2004). The study area (shown by bold outline) covers the geological units with the highest density of fission track ages (cf. Figure 3), limited to the east by the Austroalpine Silvretta nappe boundary at about $9^{\circ} 55^{\prime}$ E. (b) Cross-section following north-south transect A-B across the central Swiss Alps (modified from Schmid et al., 1996).

Figure 3-a. Map of 635 AFT ages from the Western Alps, interpolated using a naturalneighbor algorithm. Morphotectonic regions and units referred to in the text: (1) Argentera, (2) Ecrins, (3) Belledonne, (4) Mont-Blanc, (5) Aar, (6) Chur area, (7) Gran Paradiso, (8) Sesia, (9) Dent-Blanche, (10) Penninic thrust, (11) Simplon fault, (12) Periadriatic line. AFT data are compiled from Bigot-Cormier 2002; Bogdanoff et al. 2000; Bürgi and Klötzli 1990; Carpéna and Caby 1984; Carpéna 1992; Ciancaleoni 2005; Flisch 1986; Fügenschuh and Schmid 2003; Fügenschuh et al. 1999; Giger 1991; Hunziker et al. 1992; Hurford and Hunziker 1989; Hurford 1986; Hurford et al. 1991; Keller et al. 2005; Knaus 1990; Lelarge 1993; Leloup et al. 2005; Malusà et al. 2005; Michalski and Soom 1990; Pawlig 2001; Rahn et al. 1997; Sabil 1995; Schär et al. 1975; Schwartz 2000; Seward and Mancktelow 1994;

801 Seward et al. 1999; Soom 1990; Steiner 1984; Timar-Geng et al. 2004; Trautwein 2000; 802 Tricart et al. 2006; Viola 2000; Wagner and Reimer 1972; Wagner et al. 1977; Wagner et al. 
1979; Weh 1998; as well as unpublished ages provided by M. Ford, D. Seward and our own 804 data.

Figure 3-b. Map of 296 interpolated ZFT ages from the Western Alps. Numbers are as in

807 Figure 3-a. ZFT data are compiled from Bernet et al. 2001; Bigot-Cormier 2002; Bürgi and 808 Klötzli 1990; Carpéna 1992; Carpéna et al. 1986; Ciancaleoni 2005; Flisch 1986; Fügenschuh 809 and Schmid 2003; Fügenschuh et al. 1999; Giger 1991; Hunziker et al. 1992; Hurford and 810 Hunziker 1985; Hurford and Hunziker 1989; Hurford 1986; Hurford et al. 1991; Keller et al. 811 2005; Michalski and Soom 1990; Rahn 1994; Schwartz 2000; Seward and Mancktelow 1994;

812 Seward et al. 1999; Soom 1990; Vance 1999; Weh 1998; as well as unpublished ages 813 provided by M. Ford, D. Seward and our own data.

815 Figure 3-c. Interpolated map of 258 mean apatite fission-track lengths $(\mu \mathrm{m})$ from the Western 816 Alps. Short mean lengths $(<13 \mu \mathrm{m})$ indicate slow passage of the sample through the AFT 817 partial annealing zone, indicative of a slow exhumation rate. Long mean track lengths, in 818 contrast, indicate rapid exhumation. Note the strong spatial overlap between mean track 819 lengths $>13 \mu \mathrm{m}$ and AFT ages $<\sim 10 \mathrm{Ma}$ (Figure 3-a), particularly in the Simplon and Chur 820 areas, as well as more generally in the Mont-Blanc-Ecrins and the Argentera massifs. 821 Numbers are as in Figure 3-a. Apatite fission-track lengths compiled from Bigot-Cormier 2002; Bürgi and Klötzli 1990; Ciancaleoni 2005; Giger 1991; Hunziker et al. 1992; Hurford 823 and Hunziker 1989; Hurford 1986; Hurford et al. 1991; Knaus 1990; Malusà et al. 2005; 824 Michalski and Soom 1990; Pawlig 2001; Rahn et al. 1997; Sabil 1995; Seward and 825 Mancktelow 1994; Seward et al. 1999; Soom 1990; Timar-Geng et al. 2004; Trautwein 2000; 826 Tricart et al. 2006; Wagner \& Reimer 1972; as well as our own unpublished data. 
828 Figure 4. Variation of exhumation rate (Er) through time, calculated from samples with 829 paired AFT and ZFT ages. Samples with both ages younger than 35 Ma (i.e., Alpine cooling 830 ages) are used to calculate an initial rate during the time between closure of the ZFT and AFT 831 thermochronometers and a final rate for the time since closure of the AFT system (see text for 832 details). The color scale presents the ratio between final and initial exhumation rates and 833 enables to distinguish between localities where average exhumation rates have accelerated 834 (ratio $>1)$, remained steady $($ ratio $\approx 1)$ or decelerated $($ ratio $<1)$ after AFT closure. Data 835 points are labeled by their AFT age. Data origin is given in the legends of Figure 3-a and 3-b.

837 Figure 5. Generic sketch of AFT isoage surface concept. (a) Denudation (i.e., removal of 838 material) occurring between times $t_{1}$ and $t_{2}$ over the present day topography is reflected by the 839 migration of shallow isotherms, downwards with respect to the exhuming rock mass such that 840 a rock particle is cooled during exhumation (see definitions in Ring et al., 1999). The 120 - 60 $841{ }^{\circ} \mathrm{C}$ AFT partial annealing zone is shifted downwards, and so are the AFT closure temperature 842 (the temperature at which the first track is recorded) and the AFT closure surface (the surface 843 linking all samples crossing the closure temperature at a given moment). (b) Former closure 844 surfaces become isoage surfaces, younging downwards and intersecting the topography.

846 Figure 6. Steps toward the interpolation of isoage surfaces. A neighborhood search of 847 significant age-elevation relationships (AER) is performed within $3 \mathrm{~km}$ around each data 848 point $(\mathrm{a}, \mathrm{b})$. If the correlation coefficient between age and elevation is not statistically 849 significant at the $95 \%$ confidence level (b), the radius for selection of points is increased 850 stepwise up to a maximum of $15 \mathrm{~km}(\mathrm{c})$. The $A_{0}$ and $A_{1}$ parameters defining the regression 851 lines are used to interpolate the elevation of isoage surfaces between 1 Myr before the oldest 852 age selected $\left(A_{\max }\right)$ and 1 Myr after the youngest age selected $\left(A_{\min }\right)$. Finally, isoage surfaces 
853 are obtained by interpolation of isoage point arrays combining the results of neighborhood

854 AER search and the elevation of isoage contours (d). The figure shows a zoom of the

855 Lepontine area and the sources of data points are as in Figure 3a.

Figure 7. Six examples of isoage surfaces among the 13 obtained between 14 and $2 \mathrm{Ma}$.

Following a natural-neighbor interpolation between isoage points, the grid is clipped with a mask at $15 \mathrm{~km}$ to reduce the number of pixels located far from any source of information. The color scale represents the elevation in meters above sea level (note that the scale is different

861 for each panel). The overall elevation of old isoage surfaces (e.g., $11 \mathrm{Ma} ; 14 \mathrm{Ma}$ ) is higher than the elevation of younger isoage surfaces (2 Ma; $4 \mathrm{Ma})$ which is in agreement with the generic sketch in Figure 5.

Figure 8. Areas with continuous isoage surface coverage. Eight areas with isoage surfaces covering 4 to $10 \mathrm{Myr}$ were obtained by comparing the area covered by the 13 isoage surfaces obtained between 14 and $2 \mathrm{Ma}$ (Figure 6). Different periods of time are documented in different areas, as indicated in the legend, depending on the ages accessible at outcrop.

Figure 9. Calculation of denudation rate from the elevation difference of isoage surfaces. (a)

871 Map of the elevation difference between the 5 and 4 Ma isoage surfaces. (b) In this example,

872 values of elevation difference are extracted from the area of continuous isoage surface 873 coverage located on the Mont-Blanc massif (area 4 in Figure 8), and plotted in a frequency 874 histogram. The pixels with a negative value (in black on the map) cannot be used to infer 875 denudation rates and are discarded. The average distance between isoage surfaces is 876 calculated over the remaining histogram and considered to be equivalent to the amount of 877 exhumation affecting the Mont-Blanc area during the corresponding period. 
879 Figure 10. Comparison between the estimates of average denudation rate (recorded in 880 sediment volume) and exhumation rate (using AFT isoage surfaces, this study) over the 881 Western Alps. The average Western Alps denudation rate calculated by Kuhlemann (2000) is 882 the ratio between the peri-Alpine sedimentation rates (Figure 1) and the provenance area. The 883 exhumation rate was estimated over 8 regions of the Western Alps by the isoage surface 884 technique (Figures 5 to 9). Both the envelope of exhumation trend and the denudation curve 885 show an increase centered around $5 \mathrm{Ma}$. See sections 6.3. and 6.4. for a discussion of the 886 features observed in exhumation rate trends. 


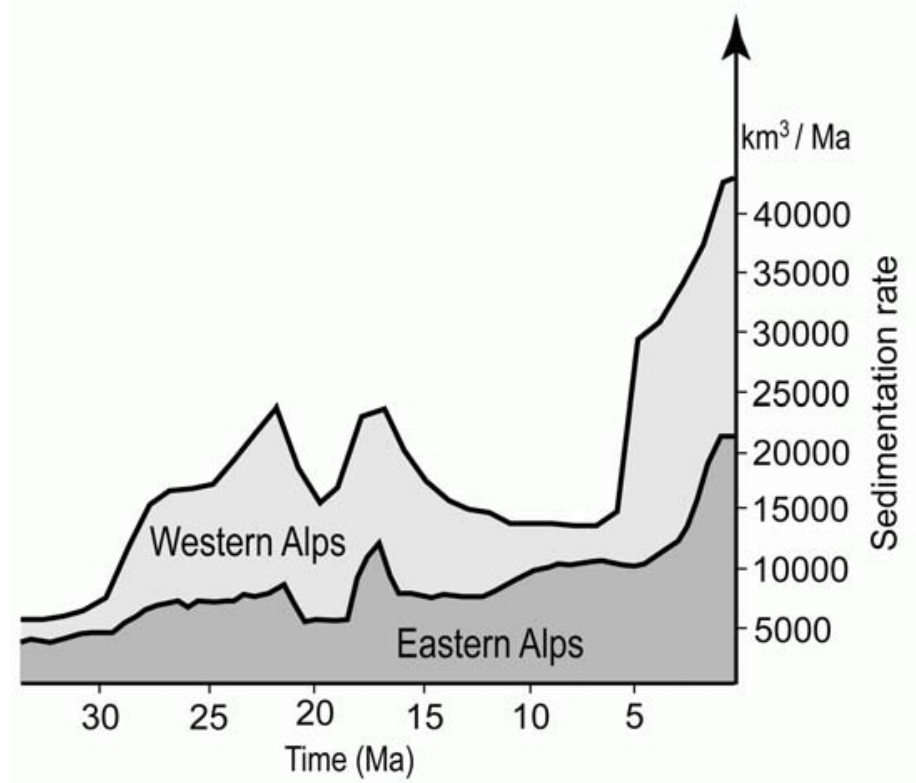

Figure 1 


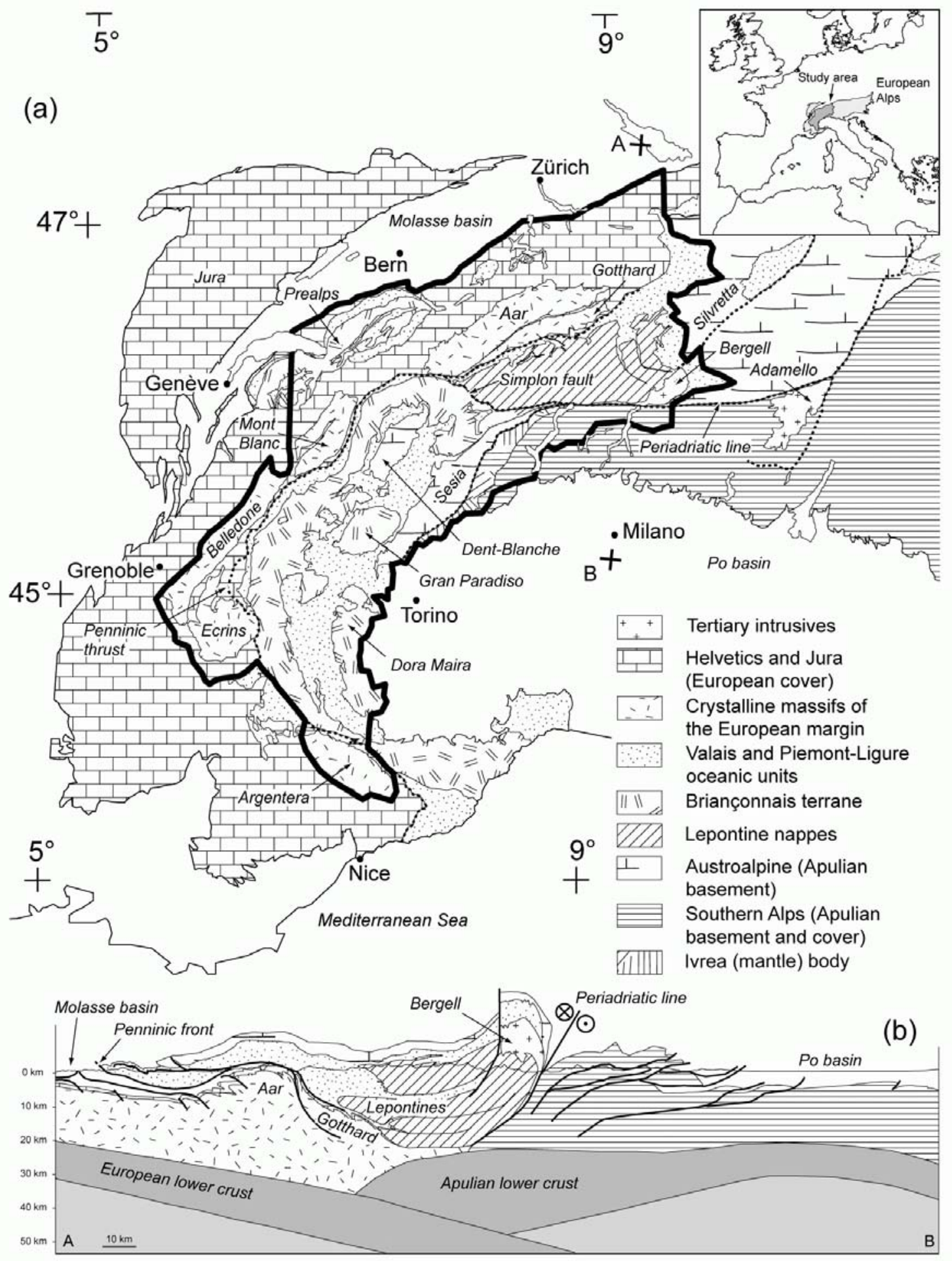

Figure 2 


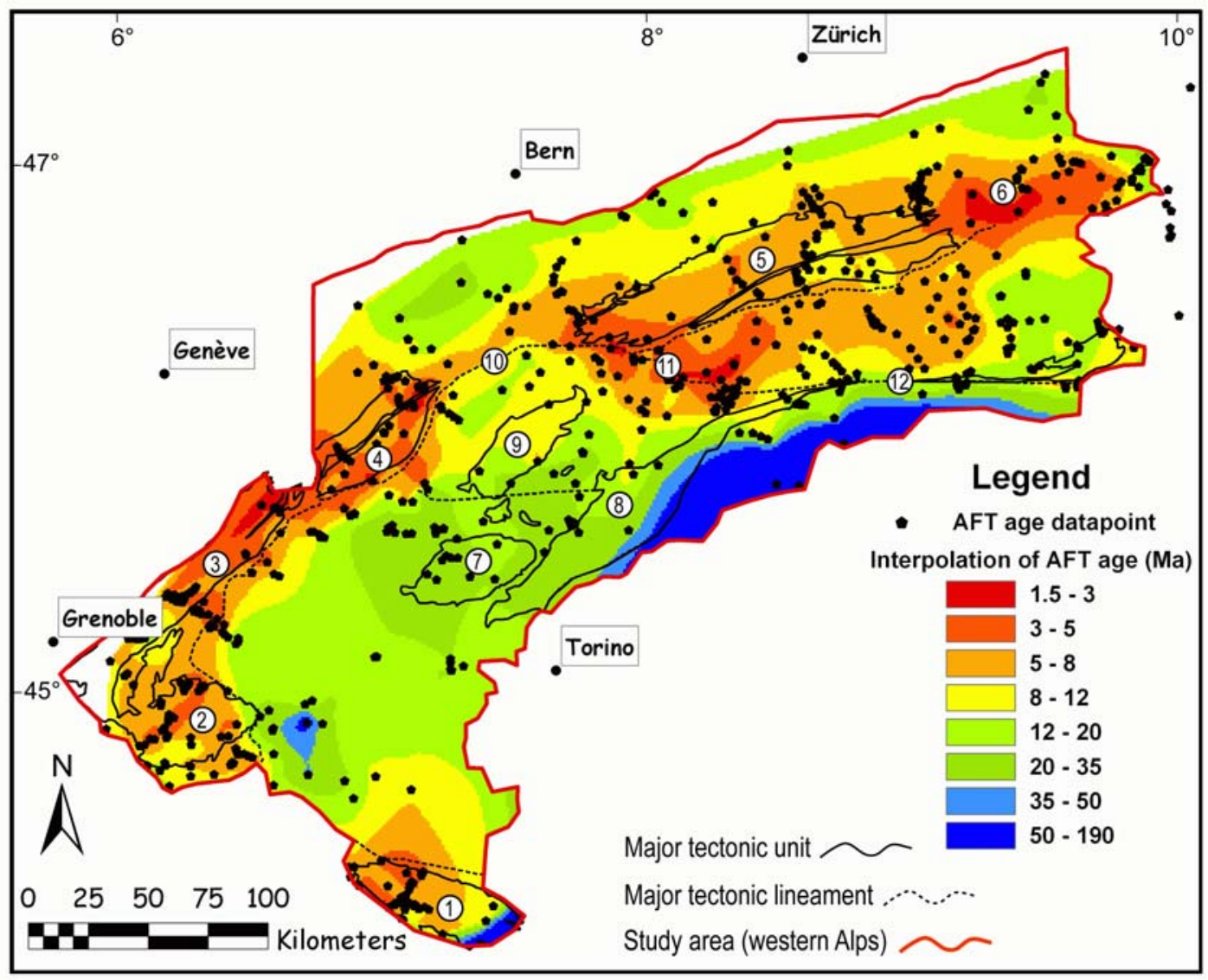

Figure 3-a 


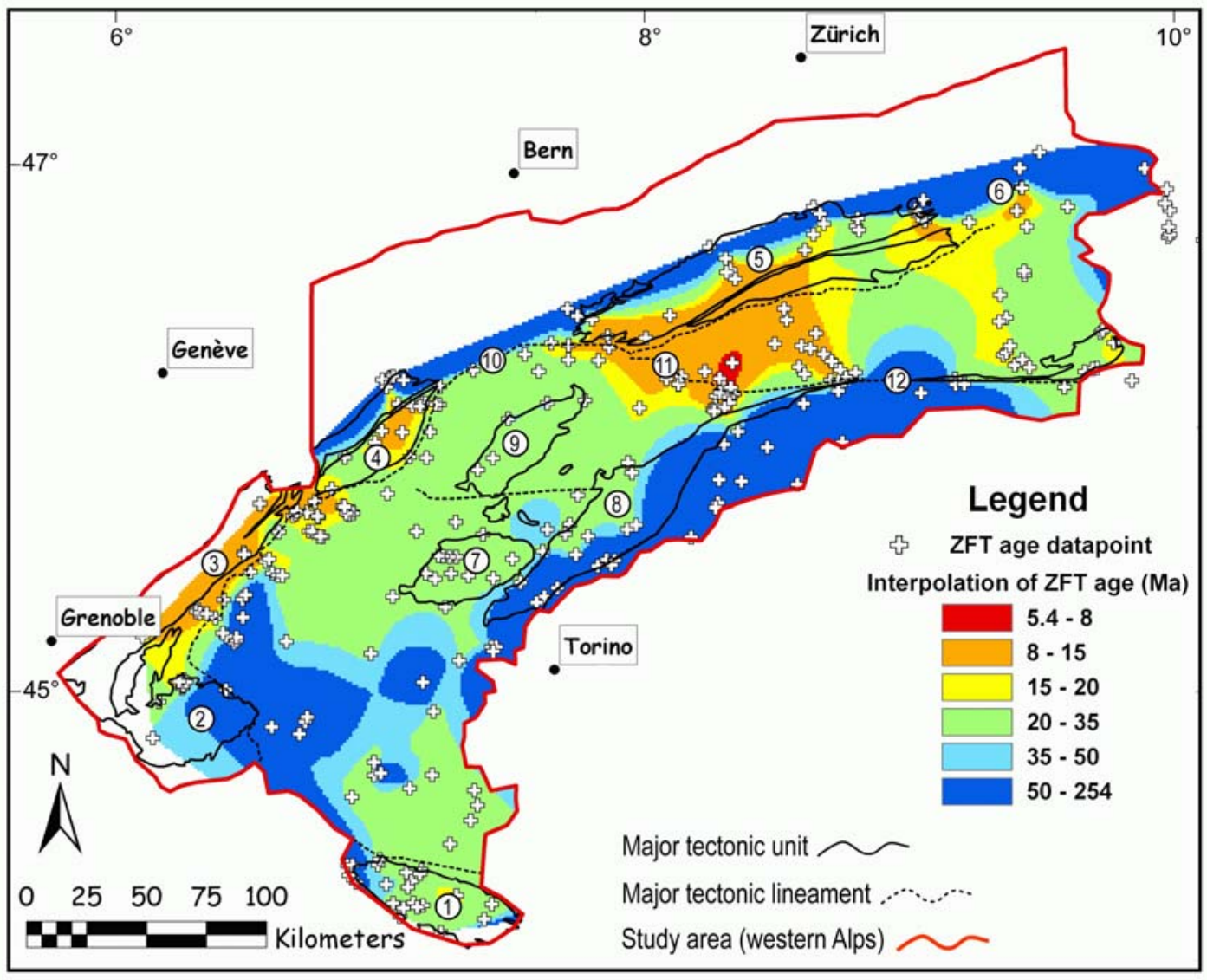

Figure 3-b 


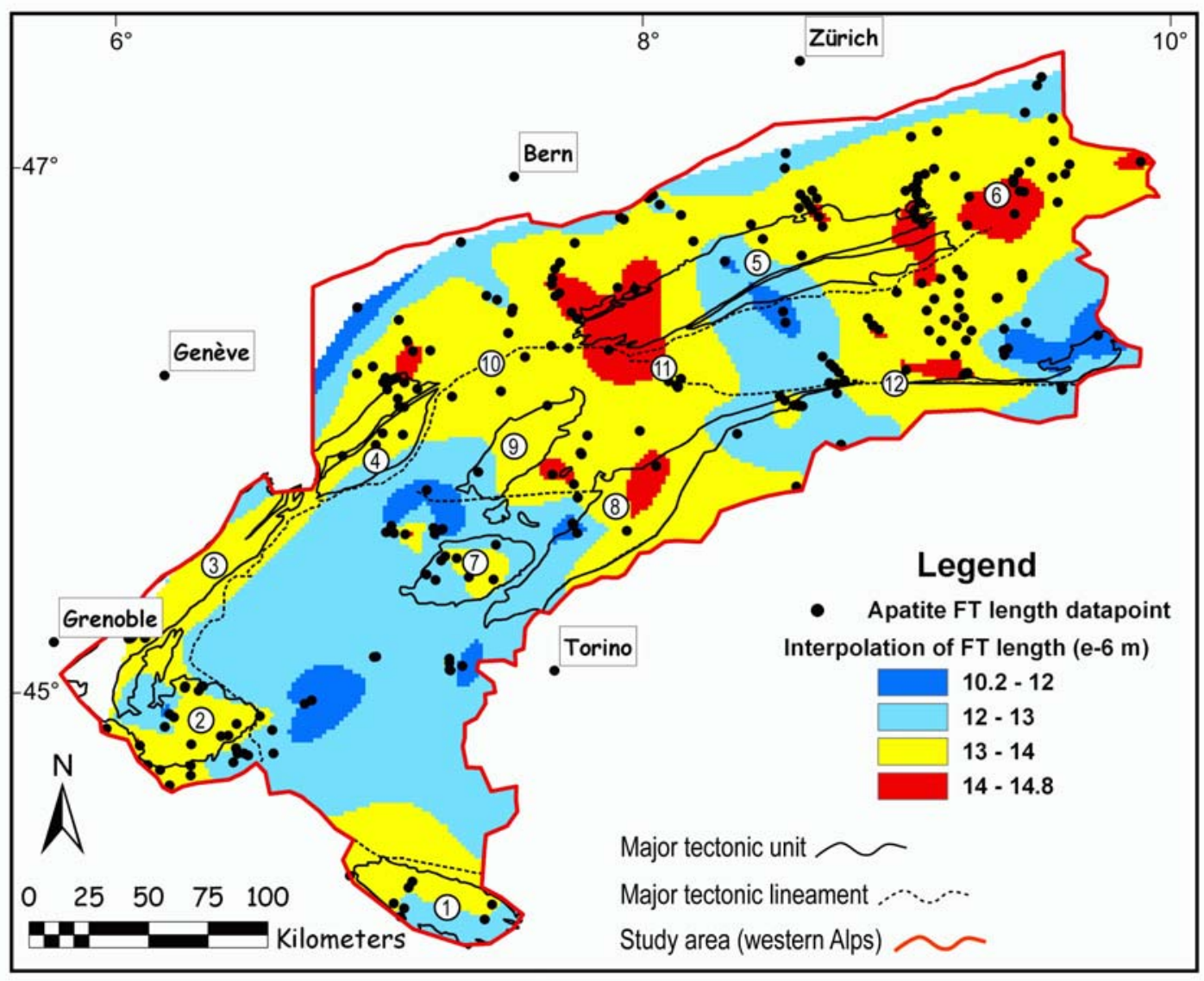

Figure 3-c 


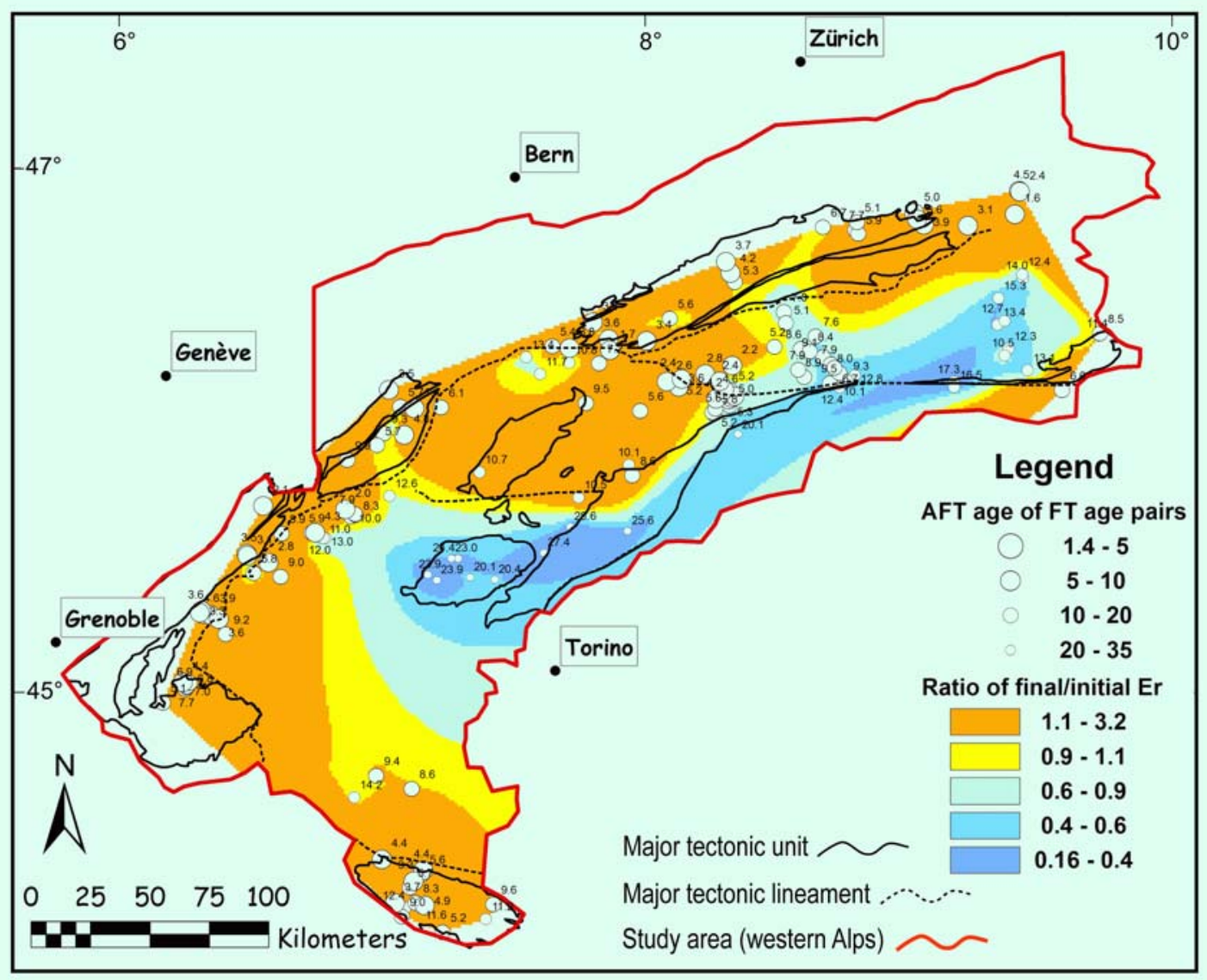

Figure 4 

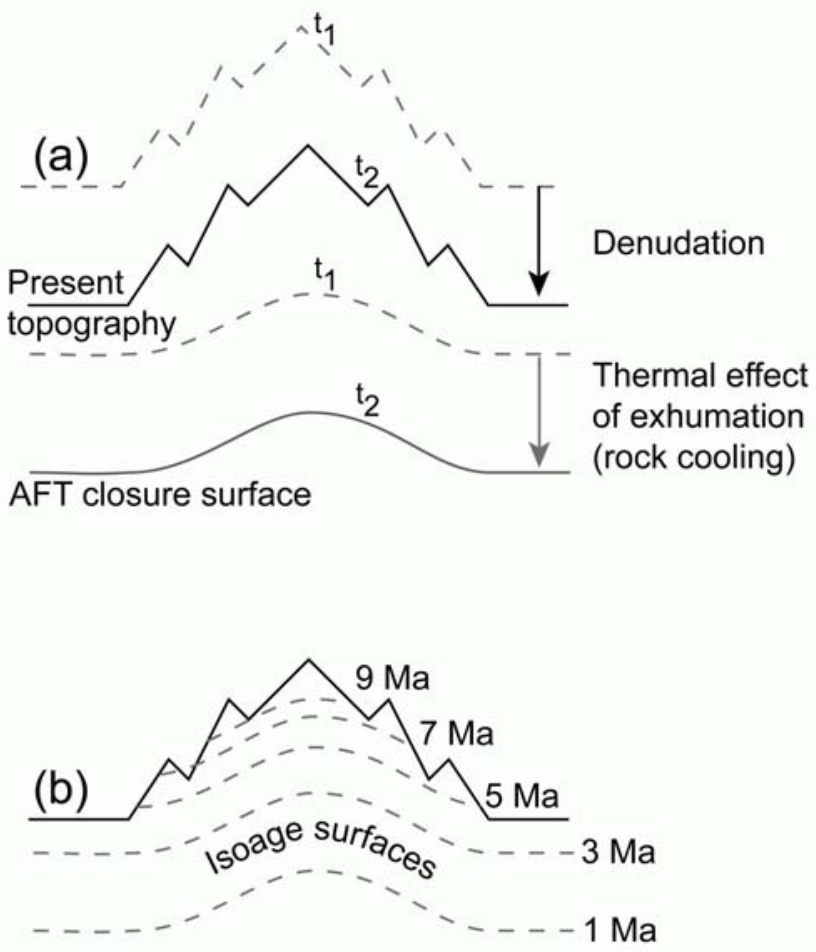

Figure 5 

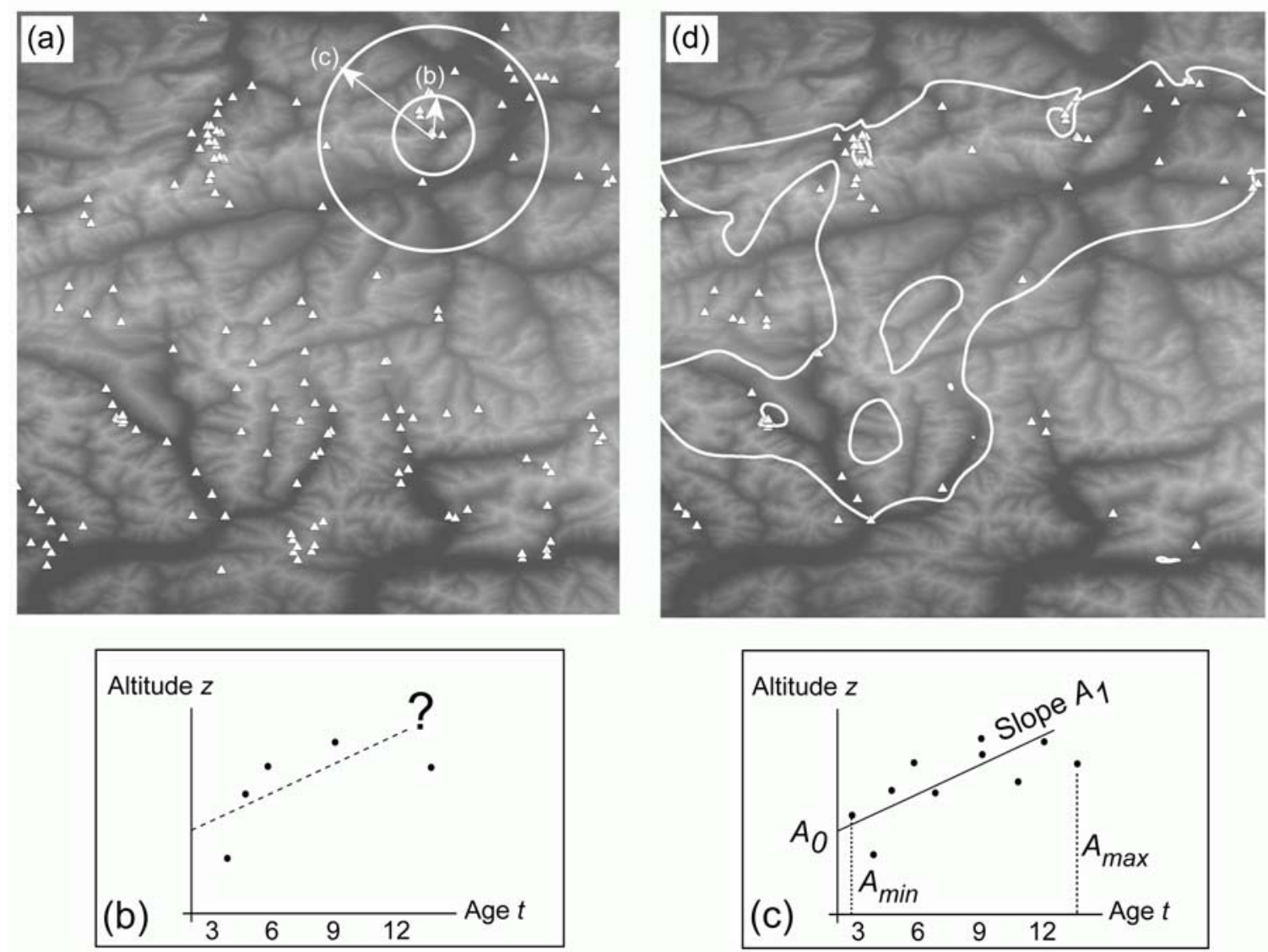

Figure 6 


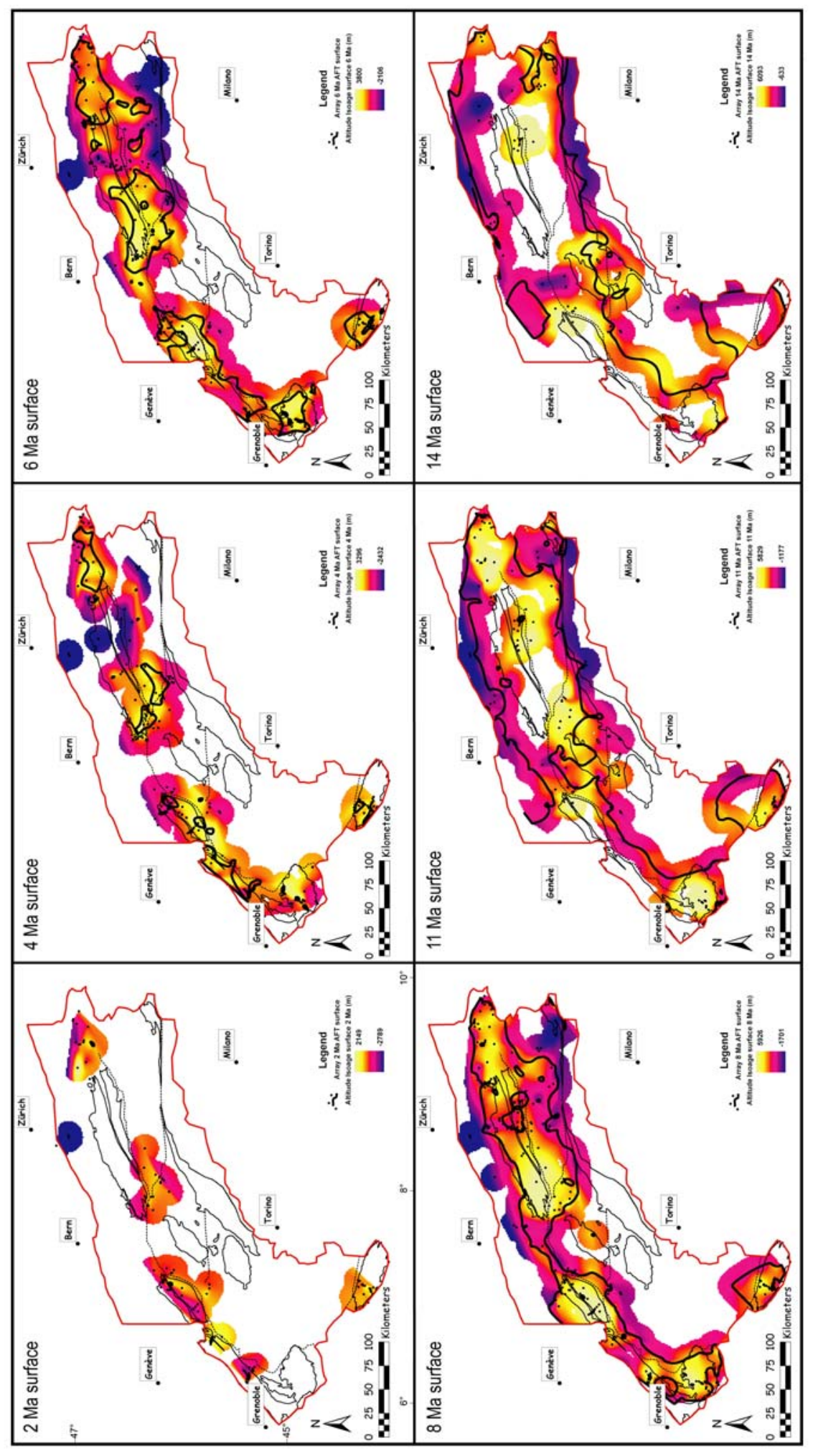

Figure 7 


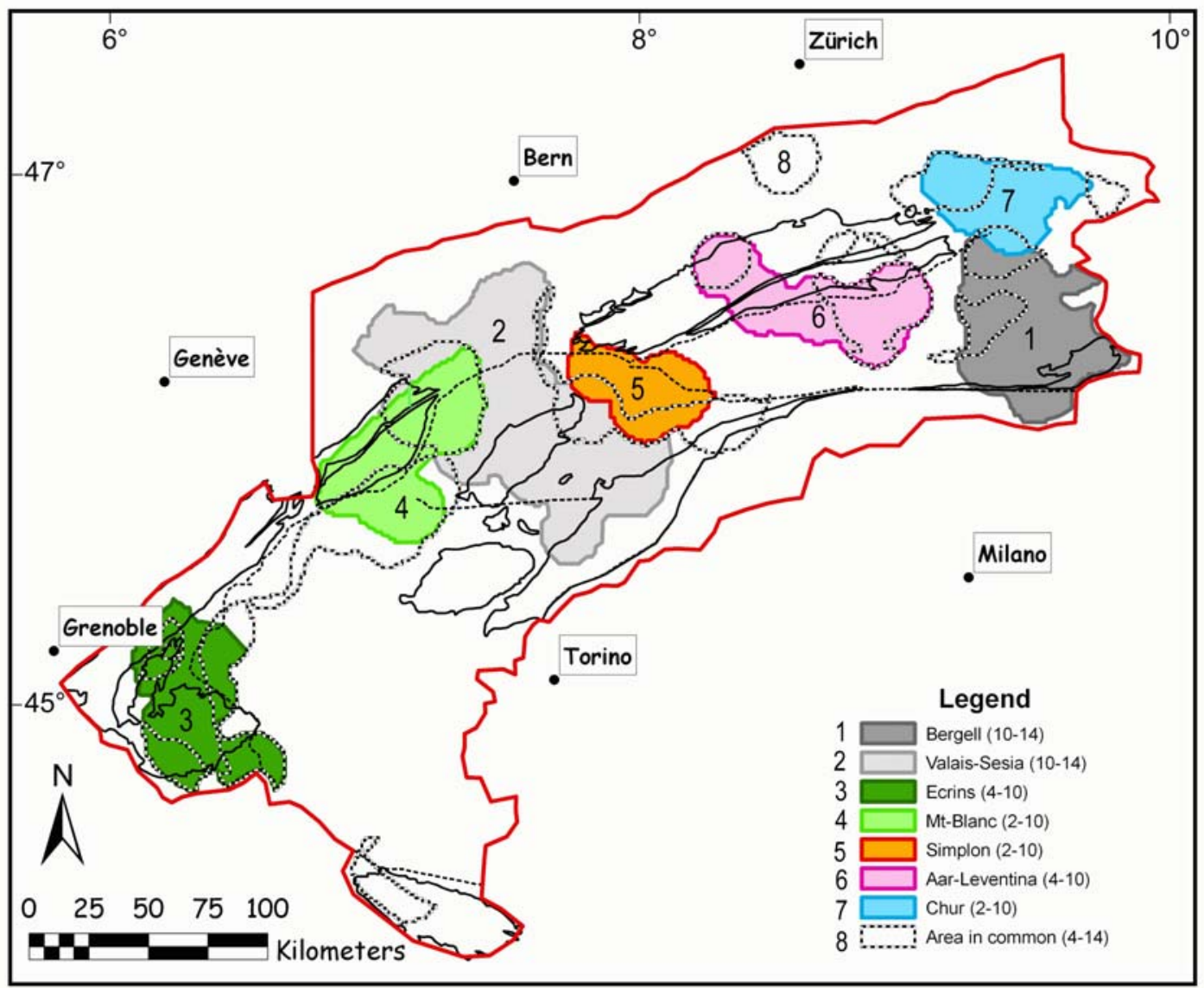

Figure 8 


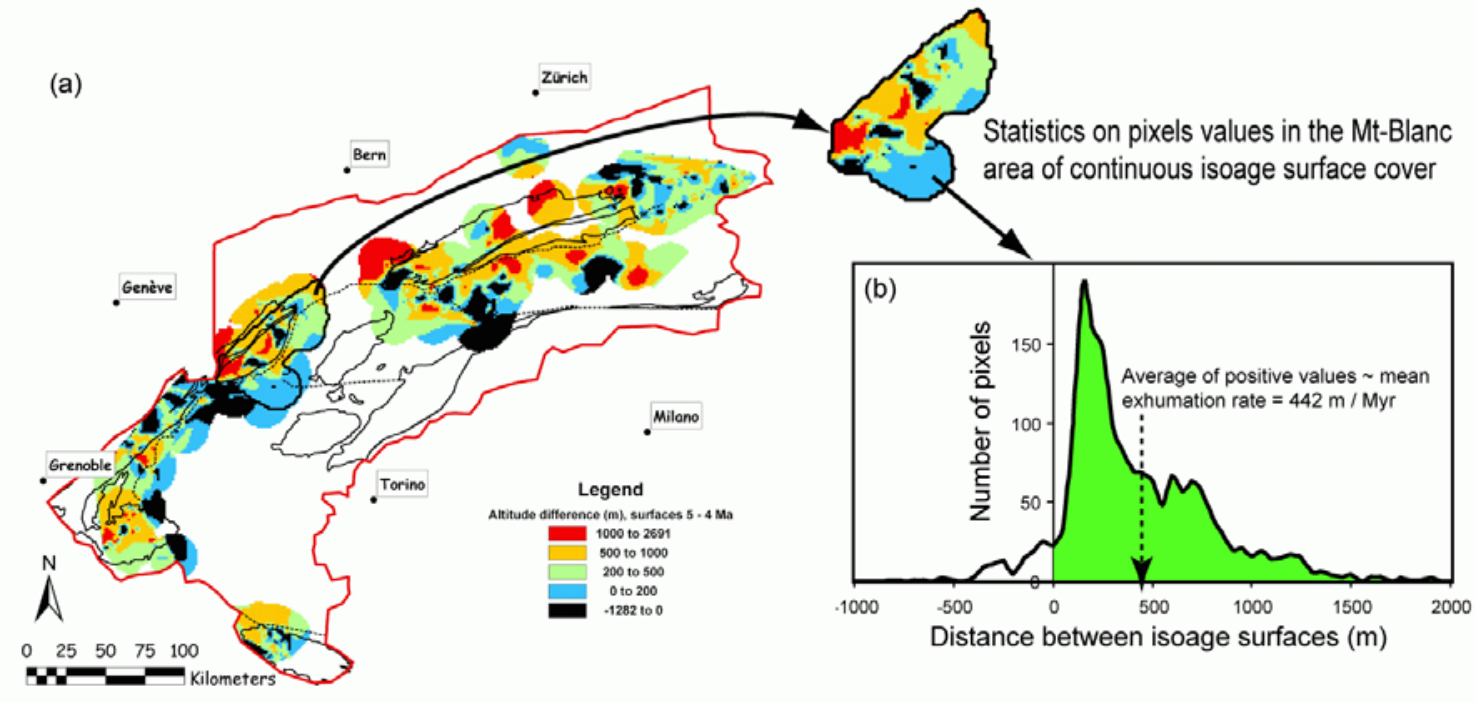

Figure 9 


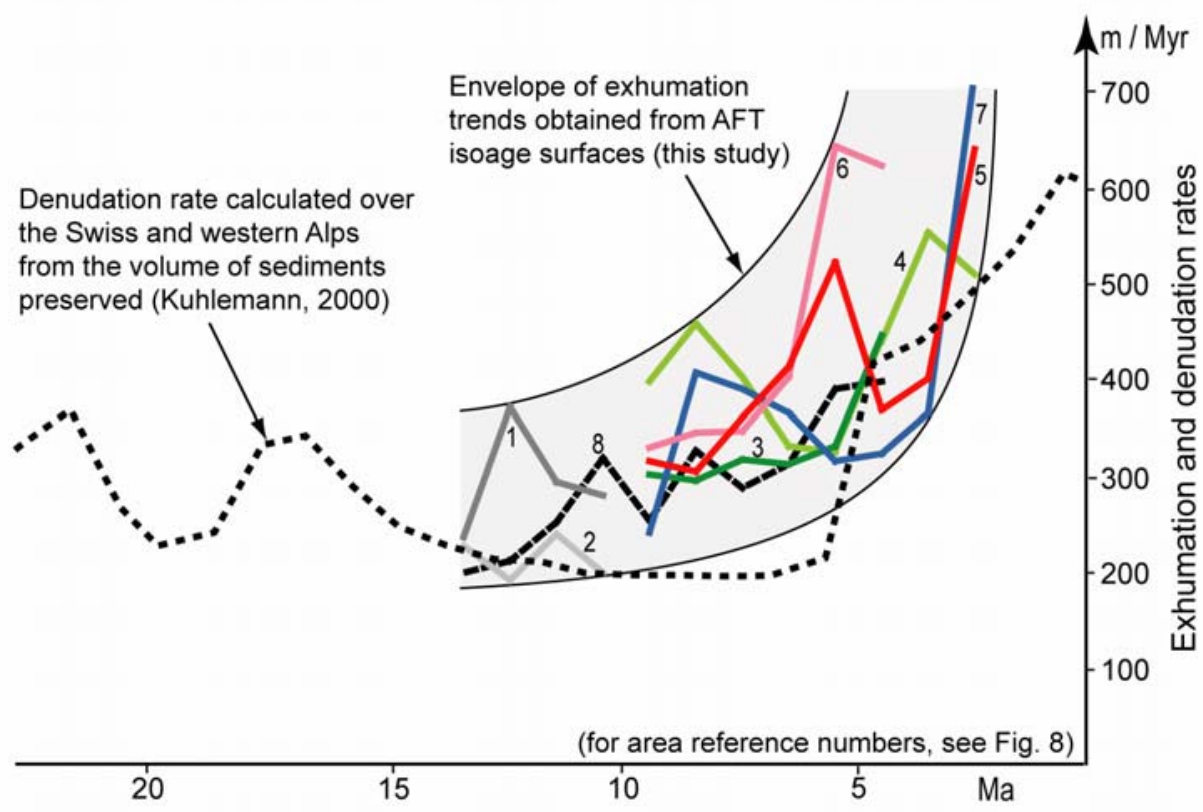

Figure 10 